\title{
CONTACTO DE LINGUAS E VARIEDADES NA EMERXENCIA DE NOVOS MODELOS DE VOCALISMO GALEGO
}

Alba Aguete Cajiao Instituto da Lingua Galega, Universidade de Santiago de Compostela DOI: 10.17075/vlcpi.2020.006 



\section{INTRODUCIÓN}

Neste traballo presentaremos os principais resultados dun estudo experimental realizado no marco da investigación dunha tese que tińa como obxectivos estudar os fenómenos de variación existentes no vocalismo galego na actualidade e analizar os posibles factores internos, externos e extralingüísticos que puidesen estar motivando esa variación. No presente capítulo presentaremos a parte desta investigación que mostra o efecto do contacto entre o galego e o castelán sobre a variación observada no vocalismo galego tónico, átono inicial e átono final da mocidade universitaria en contextos formais. O estudo ao que nos referimos foi realizado cunha mostra de falantes universitarios que tiñan como lingua inicial e de uso habitual o galego. Os datos acústicos que presentaremos foron obtidos a través da lectura dun corpus de frases que nos permitiu controlar parte da variación debida ao efecto do contexto e do ritmo. Dado que a mostra de informantes pertence a un grupo sociolectal homoxéneo, non esperabamos que houbese variación vinculada aos falantes salvo, quizais, pequenas diferenzas dialectais. Porén, os resultados revelaron a existencia de diferentes modelos de vocalismo tónico e átono inicial, vinculados fundamentalmente á procedencia dos falantes e que reflicten en gran medida o efecto do contacto co español.

Dada a poboación obxecto de estudo, os datos deben ser tomados coa debida cautela á espera dun maior número de investigacións que corroboren os resultados obtidos e permitan extrapolalos a outros contextos de uso e a diferentes perfís de falante. Pese a isto, como veremos, os resultados permítennos debuxar unha primeira panorámica da situación de variación e dos procesos de cambio en marcha que se están a consolidar na actualidade.

Este capítulo estrutúrase do seguinte xeito: comezaremos presentando as principais características fonolóxicas e fonéticas do vocalismo galego $(\$ 2)$. A seguir introduciremos brevemente os principios teóricos do contacto de linguas no mar- 
co do estudo da variación e do cambio lingüístico, centrándonos no estado da cuestión no galego (\$3). No apartado seguinte pasaremos a presentar a metodoloxía e os resultados do estudo acústico do vocalismo galego $(\$ 4)$ e para rematar, presentaremos as principais conclusións derivadas dos resultados obtidos $(\$ 5)$.

\section{O VOCALISMO GALEGO}

\subsection{Descricións fonolóxicas do vocalismo galego}

As primeiras descricións fonolóxicas do sistema vocálico galego atópanse fundamentalmente en gramáticas, entre as que podemos destacar, polo grao de detalle na descrición do vocalismo, a de Lugrís Freire (2006 [1931]) ou a de Carballo (1968). Con todo, a primeira monografía sobre fonoloxía é a Fonología gallega de Veiga (1976). Esta obra parte dunha visión estruturalista para definir o vocalismo tónico galego como un sistema vocálico triangular de dúas clases, catro graos e sete fonemas, nomeadamente /i/, /e/, / / /, /a/, / /, /o/ e /u/ (Veiga 1976). Veiga distingue o sistema tónico do sistema átono, que define como un sistema parcial, triangular, de tres clases e cinco unidades, no que opera a neutralización das oposicións entre as vogais medias altas e medias baixas das series anterior (/e/$/ \varepsilon /)$ e posterior $(/ \mathrm{o} / / / \mathrm{\rho} /)$ existentes no subsistema tónico. Distingue, ademais, un segundo subsistema átono de tres elementos en posición final de palabra, no que opera unha neutralización das oposicións entre as vogais altas e as medias altas das series anterior $(/ \mathrm{i} /-/ \mathrm{e} /)$ e posterior $(/ \mathrm{u} /-/ \mathrm{o} /)$ do subsistema átono non final (vid. Figura 1).

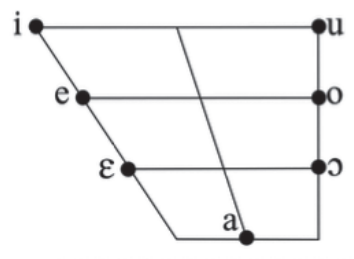

Subsistema tónico

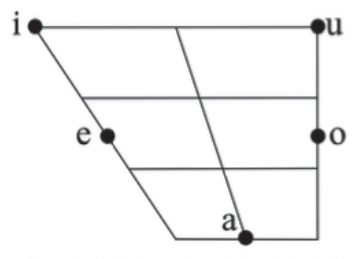

Subsistema átono non final

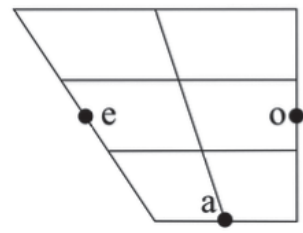

Subsistema átono final

Figura 1. Sistema vocálico tónico, átono non final e átono final do galego segundo Veiga (1976) 
As sucesivas descricións fonolóxicas do sistema vocálico do galego (Álvarez, Monteagudo \& Regueira 1995; Álvarez \& Xove 2002; Freixeiro Mato 2001, 2006) beben directamente desta descrición feita por Veiga, con escasas variacións ata o día de hoxe.

Non obstante, na década dos setenta, Santamarina (1974) constata a existencia dun cambio que afecta ao sistema átono pretónico tal e como fora descrito por Veiga. Santamarina, e posteriormente tamén Couceiro (1976), Porto Dapena (1977) e Taboada (1979), describe unha situación de coexistencia de dous modelos de vocalismo pretónico, un deles "arcaico" ou tradicional, que conservaría a neutralización das dúas oposicións anteriormente mencionadas, e un modelo "moderno", semellante ao vocalismo tónico, no que as oposicións entre as vogais medias altas e medias baixas de cada serie $(/ \mathrm{e} /-/ \varepsilon /$ e /o/-/o/) serían contrastivas. $\mathrm{O}$ autor demostra a operatividade destes contrastes tomando como exemplo a morfoloxía verbal, concretamente os cambios que sofren algúns verbos da primeira conxugación con vogal radical media baixa / $/ \varepsilon /$ ou / /. O modelo "arcaico" descrito por Santamarina caracterízase pola alternancia entre as formas rizotónicas do paradigma nas que a vogal radical é $/ \varepsilon /$ ou / / / eu voto, ['ew'ßroto]), e as formas arrizotónicas do paradigma, nas que a vogal radical sofre unha neutralización (nós votamos ['noz produce esa alternancia, senón que se mantén o timbre da vogal radical ao longo de todo o paradigma: eu voto ['ew' $\beta$ oto] nós votamos ['noz $\beta$ o 'tamos ].

$\mathrm{Na}$ lingüística galega actual asúmese que este cambio está consolidado na lingua e que se estende non só á morfoloxía verbal, senón tamén á formación de derivados con sufixos do tipo -iñola, -eirola ou -mente, que conservan a vogal media baixa da base léxica, tales como obreiro [o'ßrejro] ou roseira [ro'sejre], que tradicionalmente presentaban o resultado da neutralización da vogal da base léxica ao cambiar o acento na formación do derivado ([o'ßrrejro], [ro'sejre]). Este cambio afecta tamén á adaptación de cultismos con vogal átona inicial absoluta, que tenden a pronunciarse cunha vogal media baixa e non cunha vogal media alta, como en omitir [omi'tir] ou emitir [عmi'tir] (Regueira 2008, 2009) ${ }^{1}$.

1 Para unha revisión da fonoloxización do contraste entre as vogais medias altas e as vogais medias baixas en posición pretónica dende a Teoría da Optimalidade véxanse as interesantes achegas de Hualde \& Martínez-Gil (1994) e Martínez-Gil (2019). 


\subsection{Descricións experimentais do vocalismo galego}

Ata o día de hoxe, o número de traballos experimentais de descrición acústica do vocalismo galego é aínda moi reducido. Pese a que algúns estudos de corte dialectal da década dos setenta presentaban descricións fonéticas, o número de traballos que empregaban datos acústicos nas descricións era moi escaso (vid. Fernández Rei \& Regueira 2017).

O primeiro traballo de descrición acústica do vocalismo tónico galego é o de González González e Regueira Fernández (1994), quen analizan as vogais tónicas en contexto labial producidas por dez informantes adultos, 3 mulleres e 7 homes, de diferentes procedencias e presentan os valores medios de cada unha das vogais individualmente e no conxunto de falantes. Os resultados ofrecidos por estes autores (Figura 2), mostran un vocalismo tónico de sete vogais semellante ás descricións fonolóxicas do vocalismo galego tradicional que vimos anteriormente.

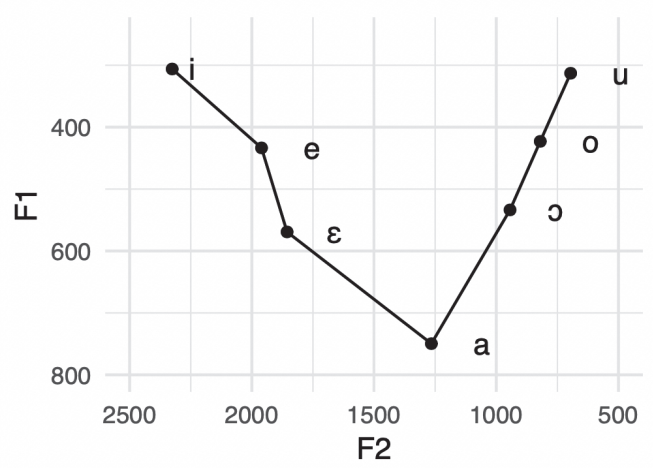

Figura 2. Valores medios das vogais tónicas do galego en contexto bilabial segundo González González \& Regueira Fernández (1994). Elaboración propia a partir dos datos de González González \& Regueira Fernández (1994)

Por outra banda, no que respecta ao vocalismo átono, cómpre destacar o traballo de Vidal Figueiroa (1997) sobre as características fonéticas de tres variedades faladas en Vigo. Pese a que non se trata dun traballo experimental, o autor describe con detalle un proceso de elevación e centralización do vocalismo átono 
final característico da variedade de galego tradicional baseándose na súa propia percepción.

Alén do traballo de Vidal Figueiroa, unicamente temos constancia de dúas descricións acústicas do vocalismo átono en posición final absoluta de palabra (Molinos Castro 2002; Regueira 2007). Molinos Castro (2002) realiza un estudo experimental de fala de laboratorio cunha mostra de 30 informantes galegofalantes rurais pertencentes a dous grupos diferenciados: falantes de entre 40 e 55 anos con estudos primarios e falantes de entre 19 e 25 anos con estudos superiores. Aínda que o obxectivo da súa investigación é o vocalismo átono en final de palabra fonolóxica, a autora presenta datos do vocalismo tónico como base de comparación. Neste traballo, constátase a existencia do fenómeno de elevación e centralización do vocalismo átono final con respecto ao tónico descrito por Vidal Figueroa, como se mostra na Figura 3. Regueira (2007) obtén resultados semellantes aos de Molinos Castro nun estudo no que compara o vocalismo átono final do galego, a partir de tres falantes de galego procedentes de Vilalba, e do portugués, representado por falantes de Porto e Braga, en tres posicións prosódicas diferentes.

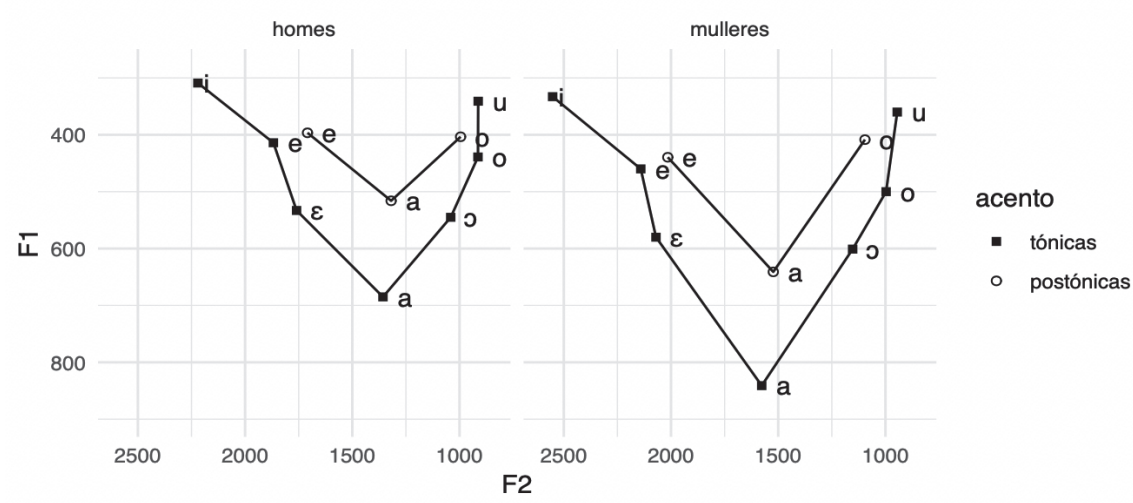

Figura 3. Valores medios das vogais tónicas (cadrados) e átonas finais (círculos) do galego segundo o estudo de Molinos Castro (2002). Elaboración propia a partir dos datos de Molinos Castro (2002) 
Xa que logo vemos que, mentres que os traballos de descrición puramente fonolóxica puñan o foco sobre a redución no número de unidades no vocalismo átono con respecto ao tónico, os traballos de corte empírico mostran que esa redución do número de unidades vai acompañada dun proceso de redución no espazo acústico semellante ao que sofre o vocalismo do portugués europeo (Bisol \& Veloso 2016; Veloso 2016).

\section{O CONTACTO DE LINGUAS E VARIEDADES NO ESTUDO DA VARIACIÓN E O CAMBIO LINGÜÍSTICOS}

O estudo e interpretación da variación e do cambio lingüístico é un dos principais crebacabezas dos que se vén ocupando a lingüística. Se nos inicios da disciplina as teorías lingüísticas trataban de achegarse á variación entendendo as linguas como entes vivos e independentes dos individuos e das comunidades de fala, nas últimas décadas púxose o foco no papel dos falantes como axentes de difusión dos cambios (Jones \& Esch 2002; Silva Valdivia 2013: 291).

Se ben é certo que os planos social e estrutural da linguaxe son inseparables na realidade, no estudo do cambio lingüístico adóitanse distinguir, por razóns metodolóxicas, tres grandes clases de factores que desencadean a variación e o cambio lingüístico. Adoita distinguirse entre: i) os factores internos ou factores sistémicos, é dicir, aqueles nos que a variación vén motivada pola propia estrutura e pola natureza da lingua; ii) os factores externos ou contact-driven (Jones \& Esch 2002), que son fundamentalmente factores debidos ao contacto de linguas; e iii) os factores extralingüísticos, é dicir, aquelas motivacións sociopolíticas, socioeconómicas e sociopsicolóxicas (factores identitarios e actitudinais) que conducen ao cambio lingüístico (Jones \& Esch 2002; Torgersen \& Kerswill 2004; Hinskens et al. 2005) $)^{2}$. Como xa comentamos, esta distinción non é máis que un método de traballo co que abordar o estudo da variación e do cambio lingüístico, mentres que na realidade é difícil, se non imposible, diferenciar a natureza do factor principal involucrado en cada un dos fenómenos de variación e cambio lingüísticos.

\footnotetext{
2 Non todos os autores coinciden na división entre os factores externos e os factores extralingüísticos, senón que en moitos casos a división establécese unicamente entre os factores internos e os factores externos (vid. Hickey 2012; Milroy, 2003; Croft 2000).
} 
Con respecto ao primeiro tipo de factores, un determinado fenómeno de variación pode estar motivado pola estrutura interna da lingua coa finalidade de mellorar un determinado contraste, tanto sintagmático coma paradigmático, mediante mecanismos como a epéntese, a metátese ou a disimilación, ou ben coa finalidade contraria, é dicir, para simplificar ou eliminar un determinado contraste non suficientemente rendible, por medio de mecanismos como a asimilación ou a elisión (Hume \& Johnson 2001).

$\mathrm{Na}$ variación determinada por factores externos, Jones \& Esch (2002: 9) distinguen tres direccións que pode tomar o cambio lingüístico derivado do contacto: a converxencia, a adaptación e a nivelación. O concepto converxencia fai referencia, segundo estes autores, ao proceso polo cal a influencia entre as linguas ou variedades en contacto é mutua, bidireccional e produce a confluencia de ambas as dúas linguas.

Por outra banda, co concepto de adaptación ou acomodación os autores refírense a aqueles mecanismos empregados fundamentalmente por falantes bilingües en contextos plurilingües debidos a un contexto de migración, que cómpre distinguir do mecanismo de acomodación que se produce na interacción durante a conversa. Os resultados da adaptación poden ser moi diferentes dependendo da situación concreta en que se produce, pero pode levar ben á adquisición de novos trazos ou ben á perda dos trazos característicos da variedade propia (véxase Auer 2007 para unha revisión pormenorizada).

Finalmente, o concepto de nivelación $n^{3}$ utilízase para describir o proceso polo cal nunha determinada variedade lingüística se eliminan as variantes marcadas. Este proceso pode darse verticalmente, onde a variedade de menor prestixio se adapta á variedade de maior prestixio, ou horizontalmente, onde se reduce a variación existente entre variedades do mesmo status, mais, en ambos os dous casos, unha das variedades actúa como variedade de referencia.

A interpretación dunha determinada característica lingüística como marcada ou prominente (Kerswill \& Williams 2002; Labov 2006; Trudgill 1986) débese,

3 Os termos converxencia e nivelación poden atoparse expresando nocións lixeiramente diferentes ás que aquí expońemos. Autores como Berruto (1995: 225, citado en Hinskens et al 2005: 11) empregan o termo converxencia no sentido referido aquí para a nivelación vertical e o termo nivelación (dialectal) para o que aquí denominamos nivelación horizontal. Con todo, neste traballo optamos por unha noción do termo converxencia no sentido máis estrito que implica unha influencia recíproca, unha aproximación de ambas as dúas linguas ou variedades (véxase tamén Berruto 2005). 
como sinala Dubert García (2002), a un proceso de representacións mentais subxectivas construídas socialmente e, polo tanto, non é unha relación estática, senón que varía dependendo dos contextos específicos e das comunidades de fala. $\mathrm{Xa}$ que logo, nun contexto de contacto de linguas, a razón pola que un determinado fenómeno de variación se expande débese, en última instancia a razóns puramente extralingüísticas. Entre estes factores extralingüísticos atópanse, como comentamos anteriormente, as actitudes lingüísticas dos falantes cara a unha determinada lingua ou variedade, así como a identificación dos propios falantes como parte das comunidades de fala. Polo tanto, un determinado fenómeno de variación pode resultar nun cambio lingüístico se os falantes establecen unha relación entre esa forma lingüística e unha determinada variedade ou grupo. As consecuencias disto poden ser que i) os falantes traten de empregar ese trazo para aproximarse ao grupo de referencia co que se senten identificados, ou ii) que traten de evitar ese trazo para distanciarse dese grupo (Stevens \& Harrington 2014: 8). É dicir, unha determinada variante existente derivada do contacto de linguas pode ser empregada conscientemente polos falantes para expresar a súa identidade dentro da comunidade de fala e para manifestar o seu lugar na sociedade, pero tamén pode ser rexeitada polos falantes por este mesmo motivo (Dyer 2007; Gugenberger 2013).

\subsection{O efecto do contacto de linguas no vocalismo galego}

A situación de contacto existente entre o galego e o castelán en Galicia non é recente, senón que se remonta á etapa de formación de ambas as dúas linguas, acentuándose progresivamente ao longo da historia Mariño Paz (1998). Pese á antigüidade deste escenario de coexistencia de ambas as dúas linguas, o uso do castelán estivo restrinxido, ata hai ben pouco, a unha minoría da poboación urbana das clases sociais máis elevadas e a determinados contextos administrativos (Monteagudo \& Santamarina 1993; Regueira \& Fernández Rei 2020).

Non é ata o século XIX, e principalmente durante o século xx cando, tras a uniformización económica, política e cultural no Estado español, se produce un cambio substancial na expansión do castelán no resto da poboación. Neste momento iniciouse, ademais, un importante cambio demográfico como consecuencia do despoboamento do interior cara á costa (Mariño 1998; Monteagudo, 
Loredo Gutiérrez \& Vázquez 2016). Esta desruralización, que se viu acentuada a partir da década de 1960, tivo unha serie de efectos sociolingüísticos notables: o cońecemento e uso do castelán, que ata ese momento era a lingua empregada por unha minoría urbana, convértese nun símbolo de ascenso social que acelera o proceso de substitución lingüística do galego polo castelán.

Coñecer estas particularidades históricas sobre a transversalidade do contacto entre galego e castelán nas diferentes capas da sociedade é fundamental en tanto que permite explicar por que o contacto co español afectou de diferente xeito a uns aspectos da gramática e non a outros. Aínda que o efecto do contacto entre o galego e o castelán é recíproco, tivo unha especial repercusión no léxico de ambas as dúas linguas. Pola contra, nos planos fonético ou morfosintáctico a influencia do español sobre o galego tivo unha incidencia máis recente, posto que en xeral as interferencias nestes dous planos funcionaron en sentido inverso, é dicir, do galego cara ao castelán (Rojo 2005; Silva Valdivia 2013).

Esta situación provocou que a investigación acerca do efecto do contacto co español sobre o galego estivese centrada fundamentalmente na integración de préstamos do castelán no léxico galego (véxase, entre outros Fernández Salgado 2004; Gugenberger, Monteagudo \& Rei-Doval 2013; Iglesias Álvarez 2016; Loredo Gutiérrez \& Silva Valdivia 2014; Negro Romero 2009, 2013) e en menor medida nos planos morfolóxico, sintáctico ou fonético e fonolóxico da gramática (Dubert García 2005; Silva Valdivia 2006, 2004).

No que atinxe ao plano fonético e fonolóxico, e concretamente ao vocalismo, que é o que aquí nos ocupa, atopamos un amplo repertorio de referencias á adquisición "imperfecta” (Siegel 2008; Muysken \& Smith 1995; Thomason 2001, 2010) dos padróns fónicos do galego por parte de falantes que teñen o galego como segunda lingua, fundamentalmente neofalantes (Freixeiro Mato 2014; González González 2008; Monteagudo \& Santamarina 1993; Regueira 2012, 2013). Así, por exemplo, acerca do vocalismo, Regueira (2013) fai a seguinte observación:

Os profesionais que proceden de ambientes galegofalantes e algúns "neofalantes" mostran as características que consideramos básicas da lingua galega: 7 vogais en posición tónica e pretónica, vogais finais átonas moi pechadas [...]. Polo contrario, a maioría de "neofalantes” e dos castelanfalantes teñen un sistema fonolóxico coincidente co do español (5 vogais tónicas, vogais átonas semellantes ás tónicas, entoación) (Regueira 2013:12). 
Así e todo, a maior parte destas descricións son de corte impresionista e fan referencia, en xeral, ás características fonéticas ou aos sistemas fonolóxicos de falantes que teñen o galego como segunda lingua e, polo tanto, están a reflectir as limitacións existentes no proceso da adquisición da compoñente fónica do galego por falantes que non teñen esta lingua como lingua inicial (Best, McRoberts \& Goodell 2001; Flege 1993) e non propiamente un fenómeno de variación no galego producido polo contacto co castelán ${ }^{4}$.

Os traballos de corte experimental sobre os efectos do contacto no plano fonético e fonolóxico son, como comentamos anteriormente, bastante recentes. Cómpre destacar aquí unha liña de investigación novidosa no ámbito galego, non directamente enfocada aos efectos do contacto entre o galego e o castelán, senón orientada á adquisición da compoñente fonético-fonolóxica, pero que nos proporciona, de maneira indirecta, unha importante fonte de datos empíricos sobre o vocalismo galego na actualidade.

O primeiro destes traballos é o de Amengual \& Chamorro (2015) quen investigan, a través da percepción e da produción, como unha maior exposición ao castelán afecta ao proceso de adquisición dos contrastes entre as vogais medias altas e medias baixas do galego (/e/-/ع/ e /o/-/o/), e que observan unha correlación positiva entre o grao de dominancia en galego e a robustez destes contrastes.

Nesta mesma liña atópanse os traballos de Tomé Lourido e Evans (Tomé Lourido 2018; Tomé Lourido \& Evans 2015, 2019), enfocados á adquisición destes mesmos contrastes (/e/-/E/ e /o/-/o/), así como á produción das vogais átonas finais por parte de neofalantes ${ }^{5}$ en comparación con falantes dominantes en galego e con falantes dominantes en castelán. Os resultados que obteñen mostran que só os dominantes en galego de procedencia rural manteñen estas oposicións, fronte aos dominantes en castelán e os neofalantes rurais, que fusionan as vogais medias altas e medias baixas, mentres que os galegofalantes urbanos e os neofalantes urbanos producen categorías intermedias entre as dos outros dous grupos. Por outra banda, os resultados relativos ás vogais finais átonas (Tomé Lourido

\footnotetext{
${ }^{4}$ Os traballos sobre o contacto entre o galego e o portugués son aínda máis escasos. Cómpre destacar as comparacións entre estes dous sistemas fonolóxicos feitas por Álvarez Blanco (1991) e Mateus (1986), así como o artigo anteriormente citado de Regueira (2007).

5 Para unha revisión do concepto de neofalante véxanse Ramallo $(2010,2013)$ e Ramallo \& O’Rourke (2014).
} 
\& Evans 2019) dan conta dun certo grao de redución do vocalismo átono final nos tres grupos de falantes (neofalantes, dominantes en galego e dominantes en castelán), se ben a redución é significativamente maior nos dominantes en galego e nos neofalantes ca nos dominantes en castelán.

Recentemente, De la Fuente Iglesias \& Pérez Castillejo (2019) analizan a produción das vogais medias altas $(/ \mathrm{e} / \mathrm{e} / \mathrm{o} /$ ) comparando as realizacións en castelán e galego de falantes bilingües procedentes de Noia. Previamente levan a cabo un test co fin de verificar se os falantes realizan as oposicións entre as vogais medias altas e as vogais medias baixas, e constatan que tanto os falantes dominantes en castelán coma os dominantes en galego da súa mostra producen eses contrastes cando falan en galego. Ademais, as autoras confirman a existencia de diferenzas significativas entre o galego e o castelán na produción das vogais /e/ e /o/, o que suxire que os mesmos falantes producen dous sistemas diferentes dependendo da lingua que están empregando.

Nesta mesma liña sitúanse os resultados obtidos por Regueira \& Fernández Rei (2020). Estes autores presentan un traballo sobre o fenómeno do contacto entre galego e castelán analizando, en ambas as dúas linguas, o sistema vocálico tónico e átono final e a entoación de falantes con catro perfís diferenciados: unha rapaza bilingüe dominante en galego, unha rapaza monolingüe en español e de procedencia urbana, dúas rapazas monolingües en castelán de procedencia semiurbana, e dúas rapazas neofalantes esenciais (vid. Ramallo \& O’Rourke 2014). Os resultados deste estudo mostran que as falantes que teñen o castelán como lingua inicial, tanto dominantes en castelán coma neofalantes, presentan, tanto en galego coma en castelán, un único sistema tónico de cinco vogais semellante ao do castelán. Pola contra, a falante bilingüe presenta dous sistemas tónicos diferenciados dependendo do idioma: un sistema de sete vogais en galego e un sistema de cinco vogais en castelán. Polo que respecta ao vocalismo átono final, os autores corroboran que todas as falantes presentan un certo grao de redución en ambas as linguas, a excepción da falante dominante en castelán de procedencia urbana.

Con todo, estes resultados son contrarios aos de López-Bueno (2017), quen analiza a produción do contraste /e/-/E/ e /o/-/o/ do galego e das vogais medias /e/ e /o/ do castelán con dous grupos de falantes, dominantes en galego e dominantes en castelán, procedentes de Vigo. Os resultados de López-Bueno mostran que 
nin os falantes dominantes en galego nin os dominantes en castelán da súa mostra producen o contraste entre as vogais medias altas e as vogais medias baixas.

Outro traballo que proporciona datos semellantes aos de López-Bueno é a recente investigación de Mayr et al. (2019), quen analizan de novo a produción do contraste entre as vogais medias altas e as vogais medias baixas do galego, así como a produción das vogais medias do castelán en tres perfís de falante: dominantes en castelán, dominantes en galego e falantes cun dobre cambio de lingua dominante ${ }^{6}$. Neste estudo, unicamente dous dos participantes do grupo dominante en galego e un dos participantes dominantes en español producían o contraste entre /o/-/o/, e só un deles producía o contraste entre /e/-/ع/.

En xeral, o conxunto destes traballos mostra que hai unha relación positiva clara entre o grao de dominio en galego e a produción de dous dos contrastes fonolóxicos, /e/-/ع/ e /o/-/o/, que diferencian o vocalismo galego do castelán. Con todo, os resultados de López-Bueno (2017) e Mayr et al. (2019) reflicten un posible cambio no sistema vocálico do galego tradicional que afecta a unha parte importante dos galegofalantes das súas mostras, segundo o cal estas oposicións xa non son realizadas polos falantes prototípicos de galego. As asimetrías existentes nos resultados proporcionados por estas investigacións pońen de relevo a necesidade de afondar nas descricións experimentais do sistema fonético-fonolóxico do galego, así como no efecto que ten o contacto co español sobre a variación existente no plano fónico.

\section{ESTUDO ACÚSTICO DO VOCALISMO GALEGO DA MOCIDADE ACTUAL}

O obxectivo deste estudo 7 , realizado baixo o marco teórico-metodolóxico da Fonoloxía de Laboratorio (Ohala 1995; Pierrehumbert 1990) e da sociolingüística variacionista (Labov 1996, 2006), era obter unha descrición acústica do vocalismo da variedade formal de galego falada pola mocidade. Para obter unha des-

\footnotetext{
${ }^{6}$ Mayr et al. (2019) denomínanos 'Dual-switch bilinguals'. Trátase de falantes educados inicialmente en galego, que cambiaron a súa lingua dominante polo castelán na infancia e que de novo pasaron a usar o galego como lingua dominante despois da adolescencia.

7 Tal e como foi exposto na introdución, os resultados que aquí se presentan forman parte dunha tese de doutoramento. Véxase Aguete Cajiao (2019) para o estudo completo.
} 
crición o máis completa posible, decidiuse estudar o vocalismo nas posicións acentuais de máxima relevancia fonética e fonolóxica, é dicir, en posición tónica, en posición átona en inicio de palabra e en posición átona en final de palabra. Así mesmo, analizouse o efecto do contexto fonético inmediato sobre a realización de cada unha das vogais, controlando tres contextos consonánticos: dental, labial e velar, que nos permitirían cońecer o campo de dispersión que ocupa cada unha destas vogais. Debido á temática deste volume, nesta publicación farase referencia unicamente á parte dos resultados relevante para o estudo do contacto de linguas.

\subsection{Metodoloxía de obtención dos datos acústicos}

Os datos deste estudo foron obtidos a través da gravación dun corpus de frases creadas especificamente para esta investigación. O corpus está formado por un total de 50 frases marco con sentido completo (vid. Táboa 1), que conteñen as palabras coas vogais obxecto de estudo en posición tónica, átona inicial absoluta e átona final e os tres contextos fonéticos anteriormente mencionados. A tarefa que tiñan que completar os participantes consistía unicamente na lectura deste corpus. Para a selección dos estímulos de elicitación das vogais tomouse como referencia a transcrición proposta no Dicionario de pronuncia da lingua galega (Regueira 2010), se ben as realizacións foron revisadas para detectar posibles diverxencias entre a realización dunha determinada palabra e a transcrición proposta por Regueira. Finalmente, só contabilizamos dous casos en que a vogal do estímulo foi realizada sistematicamente cunha vogal diferente á proposta no $\mathrm{Di}$ cionario de pronuncia: coco e etarras; ambos os dous estímulos foron etiquetados de novo de acordo á vogal producida polos falantes. 


\begin{tabular}{|c|c|c|c|}
\hline & Vogal tónica & Vogal átona inicial & Vogal átona final \\
\hline \multirow{3}{*}{ /i/ } & Fixo unha enquisa na rúa & Tedes iconas na igrexa & \\
\hline & Textos hititas e árabes & Es italiana de alma & \\
\hline & Págalles hípica hoxe & Varias hipóteses nulas & \\
\hline \multirow{3}{*}{ le/ } & Teño un bosquexo do cadro & Tedes esoutros xoguetes & Tivo un ataque secreto \\
\hline & Son un quinteto de corda & Bandas etarras na festa & Teño un picote con rosas \\
\hline & - & Ten un pecado severo & É un miope con gafas \\
\hline \multirow{3}{*}{$|\varepsilon|$} & Teño xaqueca a miúdo & Vedes eclipses de lúa & \\
\hline & Fomos a tétricas casas & Deuses eternos e fadas & \\
\hline & Es unha pécora mala & Tedes efecto rebote & \\
\hline \multirow{3}{*}{ la/ } & Hai un macaco no barco & Dúas acacias douradas & Quero a pataca sen salsa \\
\hline & Sofren metáteses varias & Hai uns atallos na esquina & Fun á picota con Ana \\
\hline & Hai unha alpaca no monte & Grandes apostas no póker & Tocan a arpa cos dedos \\
\hline \multirow{3}{*}{$/ \mathrm{s} /$} & É unha bicoca de aposta & Vedes ocasos na praia & \\
\hline & Viron un tótem na illa & Tedes otite no oído & \\
\hline & Xogan ó póker na sala & Tes os ovarios pequenos & \\
\hline \multirow{3}{*}{ /0/ } & Deulle co coco na testa & Tedes orellas de Entroido & Dálle un pataco se gaña \\
\hline & Viron dous tolos errantes & Tedes olor a papoula & Fun ó picoto con Ana \\
\hline & Pelo casposo e escuro & Temos ovellas na casa & Tedes o tempo contado \\
\hline \multirow{3}{*}{$/ \mathrm{u} /$} & Hai unha acústica mala & Dous ucraínos morenos & \\
\hline & Xogan ó tute na casa & Tes utensilios de sobra & \\
\hline & Pon a capucha no lombo & Podes upar á meniña & \\
\hline
\end{tabular}

Táboa 1. Frases empregadas na elicitación das vogais do galego

\subsection{Procesamento dos datos acústicos}

Unha vez obtidas as gravacións, cada unha das vogais foi segmentada manualmente mediante a comparación visual do espectrograma e o oscilograma en Praat (Boersma \& Weenink 2010), seguindo a metodoloxía comunmente empregada (Clopper et al. 2005: 1663).

Para cada unha das vogais segmentadas extraéronse os valores dos dous primeiros formantes (F1 e F2). Estes dous primeiros formantes representan respectivamente o grao de apertura ou de elevación da lingua e o grao de anterioridade ou posterioridade (Hayward 2000: 149-152; Rosner \& Pickering 1994: 13). Estes son os parámetros acusticamente relevantes para a descrición do vocalismo galego 
(Martínez Celdrán 1998: 41), onde a priori só existen diferenzas entre o grao de abertura e o punto de articulación. Todo este proceso foi realizado en Praat (Boersma \& Weening 2010), o que permitiu automatizar parcialmente a extracción das medidas acústicas por medio de scripts. Todos os datos foron revisados co fin de detectar posibles erros nas medicións e corrixilos cando fose necesario.

Os valores formánticos foron normalizados mediante o procedemento Lobanov (1971). A normalización dos formantes é un procedemento necesario para que os datos de diferentes falantes sexan comparables (Flynn 2011:2), xa que en xeral, o tracto vocálico dos homes é maior ca o das mulleres e os nenos, polo que a frecuencia formántica media é xeralmente menor nos homes ca nas mulleres (Rosner \& Pickering 1994: 49-55). Estas diferenzas poden verse no gráfico da esquerda da Figura 4, que mostra a dispersión dos valores non normalizados do F1 (no eixo de abscisas) e do F2 (no eixo de ordenadas) das vogais segundo o sexo dos falantes. $\mathrm{O}$ método Lobanov fai unha transformación individual para cada falante a partir do conxunto das vogais producidas, mantendo a variación sociolingüística existente entre diferentes locutores (Clopper et al. 2005: 1664), pero transformando a unha mesma escala as medidas de F1 e F2 dos diferentes falantes (gráfico da dereita da Figura 4).
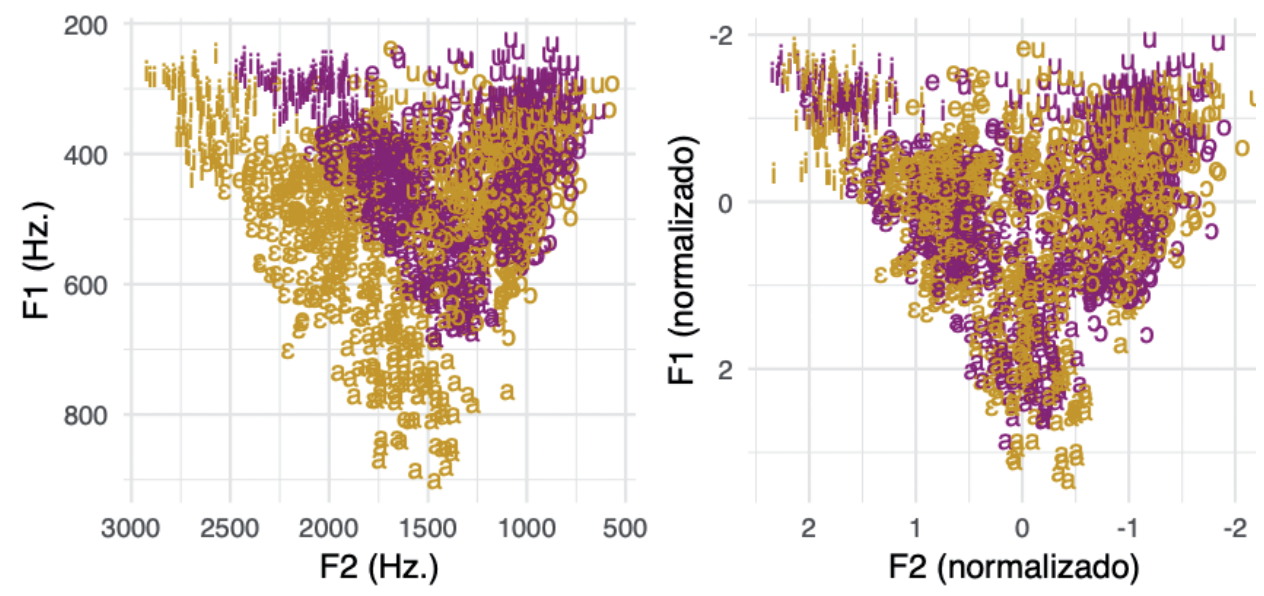

sexo

home

muller

Figura 4. Gráficos de dispersión das vogais non normalizadas (esquerda) e normalizadas (dereita) do corpus analizado 


\subsection{Metodoloxía de análise dos datos}

Os datos formánticos foron examinados e analizados en $\mathrm{R}$ ( $\mathrm{R}$ Core Team 2018) con diferentes técnicas estatísticas, co fin de comprobar o efecto das diferentes variables estudadas sobre a variabilidade existente.

Neste capítulo presentaremos os resultados exploratorios da investigación que nos permitiron observar a existencia de diferentes modelos de vocalismo tónico e átono na nosa mostra. Como vimos nos apartados anteriores, a principal característica que diferencia o sistema vocálico galego do sistema vocálico do castelán é a existencia dos contrastes entre as vogais medias altas e as vogais medias baixas, así como o proceso de redución do vocalismo átono, polo que estes serán os aspectos nos que se centrará a nosa exposición. Para cuantificar en que medida os falantes da nosa mostra presentaban eses contrastes ([e]-[c] e [o]-[o]) por medio de categorías diferenciadas, empregamos o coeficiente Bhattacharyya.
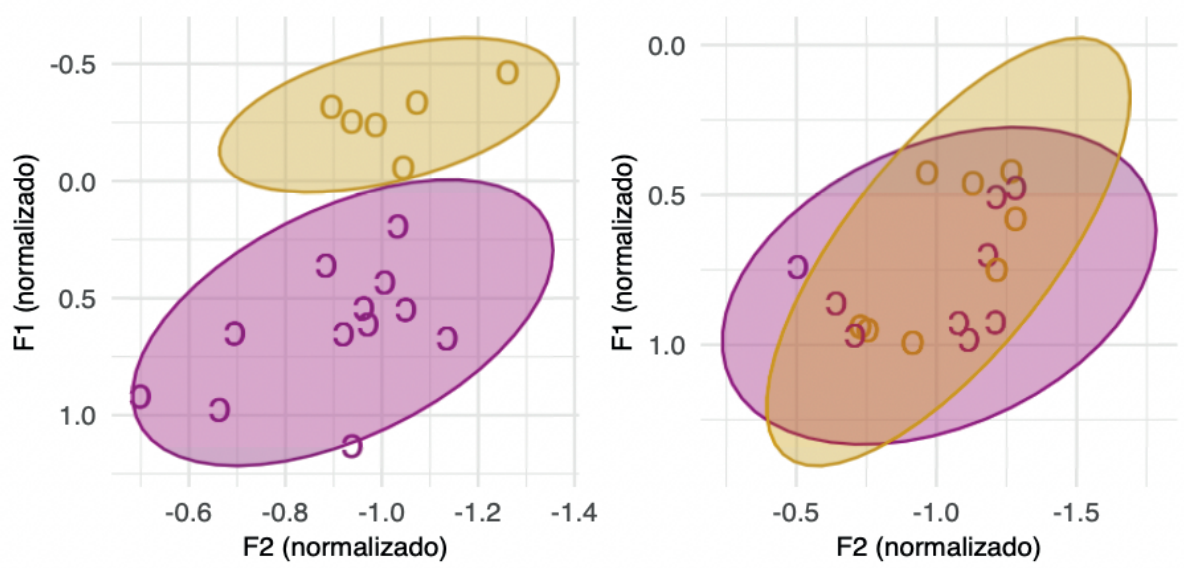

Figura 5. Distribucións bidimensionais das vogais /o/-/o/ de dous falantes diferentes cun coeficiente de afinidade Bhattachayya próximo a 0 (falante da esquerda) e cun coeficiente de afinidade Bhattacharyya próximo a 1 (falante da dereita)

Este coeficiente (Bhattacharyya 1943) é unha medida de afinidade que permite cuantificar o grao de solapamento entre dúas distribucións nun espazo bidimensional, que neste caso é o plano formado polo F1 e o F2 (Bosch-Roura 
2017: 135; Johnson 2015; Warren 2018: 311). O cálculo deste coeficiente permítenos, polo tanto, cuantificar o grao de solapamento existente entre dúas categorías vocálicas diferentes. Cando o solapamento é inexistente, como ocorre nas distribucións das vogais medias /o/-/o/ no gráfico da esquerda da Figura 5, o coeficiente obtén un valor 0 , e cando dúas distribucións están solapadas, como pode observarse para as distribucións das /o/-/o/ no gráfico da dereita da Figura 5, obtén un valor 1 . Actualmente non existe un límite, dentro dos valores que pode acadar o coeficiente, a partir do cal se considere inequivocamente que dúas vogais están ou non están fusionadas, pero claramente un valor de 0,9 indica que dúas vogais están fusionadas e un valor de 0,2 indica que as dúas vogais son categorías diferenciadas e que non están solapadas. $\mathrm{O}$ cálculo deste coeficiente permitiunos, como veremos máis adiante, establecer diferentes modelos de vocalismo en función do número de categorías vocálicas que presentasen.

\subsection{Informantes}

A mostra de datos foi producida por un grupo de 12 falantes ( 6 homes e 6 mulleres), de entre 19 e 28 anos, procedentes de diferentes localidades de Galicia e que estaban a cursar estudos universitarios no momento da gravación. Todos teñen o galego como lingua inicial de transmisión familiar e emprégano exclusivamente como lingua de comunicación habitual. Ademais, todos os informantes e as informantes teñen un nivel socioeconómico semellante.

Dados os obxectivos deste traballo, neste estudo descartouse empregar unha mostra de datos acústicos procedente de falantes que non fosen monolingües ${ }^{8}$ iniciais en galego, aínda que fosen dominantes en galego no momento de recollida da mostra, debido á influencia que a lingua materna pode ter sobre a adquisición da compoñente fonético-fonolóxica. Os diferentes traballos sobre adquisición advirten da dificultade para que un falante adquira novas categorías fonéticas e fonolóxicas (Flege 1987, 1993; Kuhl et al. 1992; Kuhl \& Iverson

\footnotetext{
8 No contexto actual galego non podemos falar propiamente de monolingüismo nas xeracións máis novas, posto que a partir da aprobación do Estatuto de Autonomía de Galicia (1980) toda a poboación é escolarizada en galego e en castelán. Neste traballo emprégase o concepto de monolingüismo co sentido específico de lingua dominante usada total ou case exclusivamente.
} 
1995; Tomé Lourido 2018), especialmente naqueles casos nos que os sistemas son moi próximos, pero non idénticos, como acontece co galego e o castelán.

O perfil lingüístico dos participantes e das participantes foi determinado por medio dunha entrevista persoal semidirixida na que se lles pedía que relatasen a súa historia lingüística, durante a que se orientaba o seu relato cara á autopercepción $\mathrm{da}(\mathrm{s})$ súa(s) lingua(s) materna(s), a(s) lingua(s) de uso habitual e as linguas inicial e habitual da nai e do pai.

A escolla dunha mostra de falantes mozos permítenos observar os fenómenos de mudanza recente. Por unha banda, a adolescencia marca unha etapa de adquisición e incorporación de cambios lingüísticos, posto que é neste momento cando os falantes gañan consciencia sobre a significación social da súa variedade e dos modelos de prestixio existentes na súa rede social (Kerswill 2013; Moreno 2009; Torgersen \& Kerswill 2004). Ademais, os participantes pertencen a unha xeración que foi completamente alfabetizada en galego, que viviu un momento da historia posterior á oficialización do galego e, ademais, dado que se trata de mozos e mozas con estudos superiores que accederon á educación en galego, asúmese que coñecen e usan a variedade estándar de galego (Monteagudo 2005: 406).

Asumimos, por tanto, a existencia dun sociolecto alto ou acrolecto galego (Dubert García 2002), é dicir, unha variedade formal de galego próximo ao estándar oral segundo foi descrito por Regueira (2010), que ten como base o sistema fonolóxico do galego tradicional (Veiga 1976). Consideramos que, para os contextos formais, esta é a variedade de referencia da poboación á que pertencen os falantes seleccionados. Asumimos, igualmente, que o contexto experimental de fala de laboratorio e a lectura de corpus escrito permite obter unha mostra de datos que reflicta a variedade formal de galego.

Os informantes foron ademais clasificados segundo o bloque dialectal e o hábitat de procedencia. Ambas as dúas variables foron estimadas a partir do seu concello de procedencia. O bloque dialectal determinouse a partir da clasificación proposta por Fernández Rei (1990), mentres que o hábitat de procedencia estableceuse en función da clasificación do grao de urbanización dos concellos do IGE (2011). De acordo con estes dous criterios, a mostra está formada por cinco falantes do bloque central de hábitat rural, catro falantes do bloque occidental de hábitat rural e por tres falantes do bloque occidental de hábitat urbano ou semiurbano. 


\subsection{Resultados}

\subsubsection{Vocalismo tónico}

Os resultados relativos ao vocalismo tónico mostran un certo grao de solapamento entre as vogais contiguas (vid. Figura $6^{9}$ ), que é significativamente maior entre as vogais medias altas e as vogais medias baixas das series anterior e posterior ca entre estas e as restantes vogais. A existencia dun lixeiro solapamento entre as categorías vocálicas próximas é un fenómeno normal dada a continuidade das vogais no espazo acústico-articulatorio. Porén, o solapamento que presentan as vogais medias altas e as vogais medias baixas de cada unha das series fai necesario analizar en detalle estas categorías.

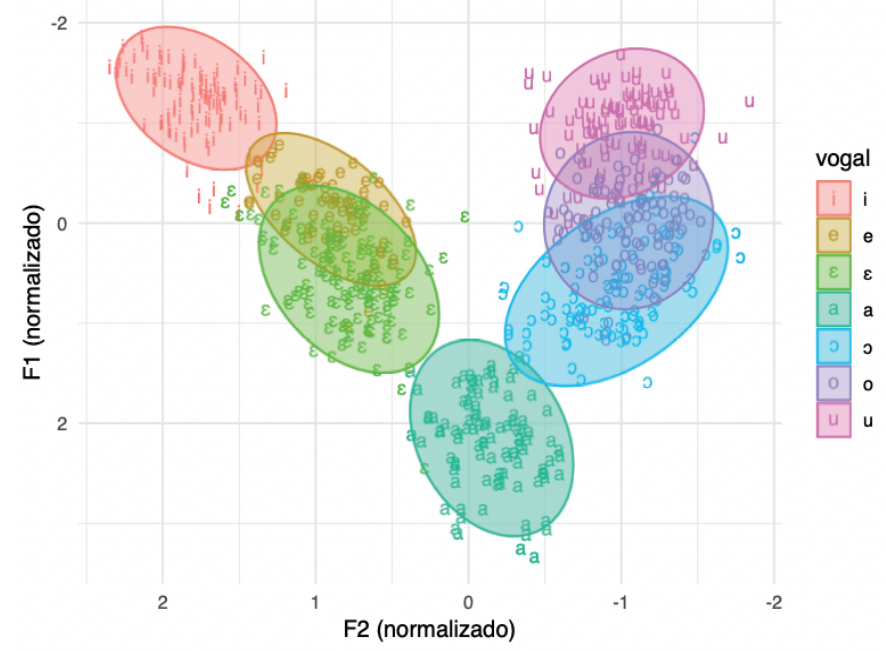

Figura 6. Gráfico de dispersión das vogais tónicas (F1 e F2 normalizados) para o conxunto de datos da mostra. As elipses marcan a dispersión con respecto á media cun intervalo de confianza do $95 \%$

9 Neste caso, o intervalo de confianza é o rango de valores arredor da media no que esperamos que se atope o $95 \%$ dos datos, e para o que aceptamos que non hai diferenzas significativas coa media observada (Baayen 2008: 81). Véxase tamén Leveshina (2015: 98-104) e Field et al. (2012: 43-49). 
Ao observarmos individualmente as realizacións de cada informante, comprobamos que os solapamentos entre as vogais medias altas e medias baixas ([e]- $[\varepsilon] \mathrm{e}$ [o]-[o]) son especialmente marcados nalgúns dos informantes, nos cales é difícil distinguir dúas categorías diferenciadas. Para poder determinar en que casos este solapamento estaba indicando unha fusión entre as dúas categorías ou só un solapamento debido á proximidade articulatoria das vogais calculouse o coeficiente Bhattacharyya (vid. Táboa 2) para cada par de vogais e para cada informante individualmente. Naqueles casos nos que o valor do coeficiente Bhattacharyya era superior a 0,5 considerouse que as vogais estaban fusionadas, mentres que cando o valor do coeficiente era inferior a 0,5 considerouse que as vogais respondían a dúas distribucións diferenciadas.

Este cálculo permítenos distinguir dous modelos de vocalismo tónico na nosa mostra, que se diferencian entre si ben polo mantemento dos contrastes entre as vogais medias altas e as vogais medias baixas [e]-[ع] e [o]-[o], ou ben pola fusión deste contraste (vid. Táboa 2), tal e como se pode apreciar nos gráficos de densidade de cada un destes modelos da Figura 7. Estes gráficos mostran a distribución dos valores de F1 e de F2 por medio da gradación de cor, de tal xeito que as zonas máis escuras representan unha maior concentración de vogais neses valores.

\begin{tabular}{|c|c|c|c|c|c|c|c|c|c|}
\hline \multicolumn{5}{|c|}{ Conservadores $(B A<0.5)$} & \multicolumn{5}{|c|}{ Innovadores $(B A>0.5)$} \\
\hline Falante & Hábitat & Bloque & {$[\mathrm{e}]-[\varepsilon]$} & [0]-[o] & Falante & Hábitat & Bloque & {$[e]-[\varepsilon]$} & [0]-[o] \\
\hline HO1 & Rural & Central & 0.02 & 0.01 & $\mathrm{HO} 2$ & Urbano & Occidental & 0.71 & 0.93 \\
\hline HO9 & Rural & Occidental & 0.34 & 0.0 & $\mathrm{H} 06$ & Urbano & Occidental & 0.72 & 0.78 \\
\hline $\mathrm{H} 10$ & Urbano & Occidental & - & 0.2 & $\mathrm{H} 10$ & Urbano & Occidental & 0.84 & - \\
\hline M04 & Rural & Central & 0.36 & 0.34 & $\mathrm{H} 11$ & Rural & Central & 0.76 & 0.78 \\
\hline M06 & Rural & Central & 0.16 & 0.45 & M05 & Rural & Occidental & 0.86 & 0.68 \\
\hline M12 & Rural & Occidental & 0.21 & 0.41 & M07 & Rural & Occidental & 0.51 & 0.85 \\
\hline M21 & Rural & Central & 0.31 & 0.1 & & & & & \\
\hline
\end{tabular}

Táboa 2. Resultados do coeficiente Bhattacharyya do solapamento de [e]-[ع] e de [o]-[0] tónicas para cada un dos falantes, agrupados segundo o modelo de vocalismo tónico que presentaban 
O modelo representado no gráfico da esquerda da Figura 7 é conservador con respecto ás características do sistema vocálico tónico tradicional do galego (Regueira 2010; Veiga 1976) posto que mantén a oposición entre as vogais medias altas e as vogais medias baixas das series anterior $([\mathrm{e}]-[\varepsilon])$ e posterior $([\mathrm{o}]-[\mathrm{\jmath}])$, mostrando sete categorías vocálicas diferenciadas. Pola contra, o modelo representado no gráfico da dereita da Figura 7 está formado por cinco vogais e tres graos de abertura, resultantes da fusión das oposicións entre [e]-[ع] e entre [o]-[o], e é coincidente co vocalismo tónico descrito para o castelán estándar (Hualde 2014: 113; Quilis 1997: 37). Como se pode observar no gráfico, as vogais medias neste modelo, innovador con respecto ao sistema vocálico do galego tradicional, sitúanse acusticamente no espazo intermedio entre as vogais medias altas e as vogais medias baixas do sistema conservador, mentres que as diferenzas entre as restantes vogais son mínimas ou inexistentes.
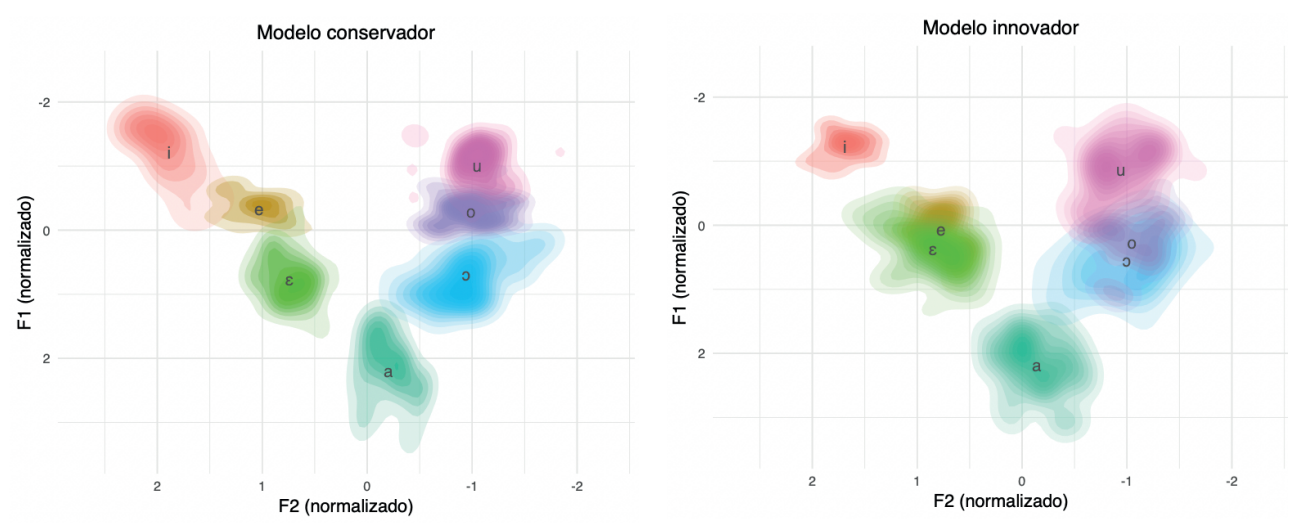

Figura 7. Gráficos de densidade do F1 e do F2 das vogais tónicas para cada modelo de vocalismo tónico presente na mostra

Tal e como se aprecia na Táboa 2 , non existen evidencias de que a variedade dialectal ou o sexo poidan estar relacionadas directamente o emprego dun ou doutro modelo. Agora ben, o hábitat de procedencia si que parece ser unha variable relevante: mentres que o modelo innovador se atopa tanto en falantes de procedencia rural como urbana, o modelo conservador só está representado en falantes de procedencia rural (coa excepción de $\mathrm{H} 10$ que realiza o contraste entre $[\mathrm{o}]-[\circ])$. 
Ante os datos existentes podemos afirmar que o vocalismo tónico está a experimentar un fenómeno de variación. Dada a similitude entre o sistema tónico do modelo innovador e o vocalismo tónico do castelán, non parece arriscado afirmar que a emerxencia deste novo modelo responde a un fenómeno de nivelación (vid. \$3) motivado polo contacto co español. Esta nivelación provocaría a homoxeneización do vocalismo galego co do español, eliminando as características marcadas do vocalismo do galego (neste caso as oposicións entre /e/-/E/ e entre /o/-/o/).

Con todo, cómpre ter en conta que hai unha serie de factores internos que tamén poden estar favorecendo que se produza este cambio. Por unha banda, os resultados mostran a existencia xeneralizada dun certo grao de solapamento entre [e] e $[\varepsilon]$ e entre $[o]$ e [o], mesmo nos falantes que manteñen o contraste. Esta tendencia parece estar reflectindo un cambio en marcha caracterizado por unha fusión por aproximación (Labov 1996), que se produce cando as distribucións dos segmentos veciños se aproximan ata non distinguirse; este proceso pode resultar nunha vogal que ocupe o espazo da distribución inicial dun dos segmentos ou ben pode resultar nunha vogal intermedia entre as dúas que se fusionan, como acontece na nosa mostra. Por outra banda, as oposicións de apertura en galego teńen un baixo rendemento ou carga funcional (Hockett 1967) se o comparamos cos restantes contrastes, o que fai que estes contrastes sexan menos robustos (Hall 2013). Estas características estruturais poden estar tamén favorecendo que se produza este cambio.

\subsubsection{Vocalismo átono inicial}

No que respecta ao vocalismo átono inicial, os resultados deste estudo mostran a existencia dunha maior variación neste subsistema ca no vocalismo tónico. Esta maior variación tradúcese nun maior campo de dispersión para todas as vogais, o cal produce tamén un maior solapamento entre as vogais contiguas (vid. Figura 8). Cómpre mencionar que unha gran parte desta variación que se observa no plano da anterioridade-posterioridade, fundamentalmente na vogal [u], é debida ao contexto consonántico, que exerce un maior efecto coarticulatorio sobre as vogais átonas ca sobre as vogais tónicas. 


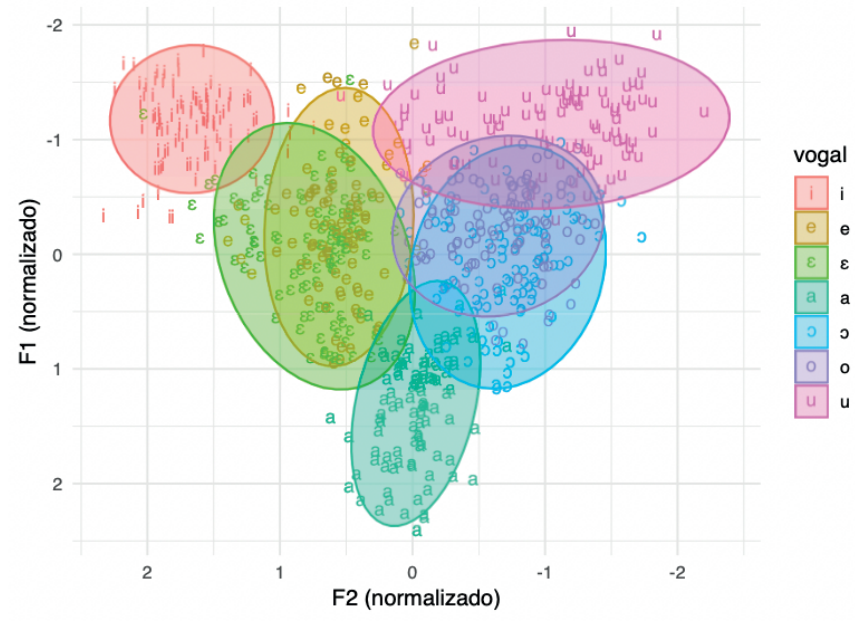

Figura 8. Gráfico de dispersión das vogais pretónicas (F1 e F2 normalizados) para o conxunto de datos da mostra. As elipses marcan a dispersión con respecto á media cun intervalo de confianza do $95 \%$

De maneira semellante ao que ocorría co vocalismo tónico, distínguense tamén dous modelos diferenciados de vocalismo átono inicial, que se mostran nos correspondentes gráficos de densidade da Figura 9 e que foron delimitados grazas á cuantificación dos coeficientes Bhattacharyya para cada par de vogais e para cada informante. De novo, estes dous modelos diferéncianse entre si por presentaren ou non as oposicións de apertura entre as vogais medias altas e medias baixas de cada serie (vid. Táboa 3). Dado que o vocalismo átono inicial presenta un maior grao de solapamento xeneralizado, considerouse o 0,65 como o limiar entre a fusión e a non fusión.

O modelo formado por sete vogais átonas iniciais, coa oposición entre $[\mathrm{e}]-[\varepsilon]$ e entre [o]-[o], correspondente co modelo denominado "moderno" por (Santamarina 1974), é minoritario na nosa mostra de datos e preséntano unicamente falantes "conservadores" con respecto ao vocalismo tónico (vid. gráfico da esquerda da Figura 9). Ademais, en dous dos catro casos o grao de solapamento entre [e]-[ع] é moi elevado, con valores próximos ao limiar de 0,65. 


\begin{tabular}{llllllllll}
\hline \multicolumn{3}{c}{ (BA < 0.65) } & & \multicolumn{5}{c}{ (BA > 0.65) } \\
\hline Falante & Hábitat & Bloque & {$[\mathbf{e}]-[\varepsilon]$} & {$[\mathbf{0}]-[\mathbf{0}]$} & Falante & Hábitat & Bloque & {$[\mathbf{e}]-[\varepsilon]$} & [0]-[0] \\
\hline H01 & Rural & Central & 0.27 & 0.27 & H02 & Urbano & Occidental & 0.72 & 0.67 \\
H09 & Rural & Occidental & 0.63 & 0.37 & H06 & Urbano & Occidental & 0.83 & 0.77 \\
M06 & Rural & Central & 0.09 & 0.32 & H10 & Urbano & Occidental & 0.79 & 0.86 \\
M21 & Rural & Central & 0.57 & 0.33 & H11 & Rural & Central & 0.86 & 0.92 \\
& & & & & M04 & Rural & Central & 0.80 & 0.87 \\
& & & & & M05 & Rural & Occidental & 0.81 & 0.86 \\
& & & & & M07 & Rural & Occidental & 0.89 & 0.85 \\
& & & & & M12 & Rural & Occidental & 0.78 & 0.77 \\
\hline
\end{tabular}

Táboa 3. Resultados do coeficiente Bhattacharyya do solapamento de [e]-[ع] e de [o]-[0] átonas iniciais para cada un dos falantes, agrupados segundo o modelo de vocalismo átono inicial que presentaban

Por outra banda, o vocalismo pretónico de cinco unidades (vid. gráfico da dereita da Figura 9), que a priori se correspondería co modelo "arcaico" de Santamarina, é empregado tanto por aqueles falantes que presentaban un vocalismo tónico innovador coma por falantes conservadores. Dado que a evolución histórica do vocalismo átono nas linguas romances tivo como resultado un sistema de cinco vogais (Lausberg 1971: 252-255), parece difícil determinar se o resultado que vemos aquí se debe á conservación deste vocalismo pretónico "histórico" ou ao efecto do contacto co castelán, polo cal se simplificaría o vocalismo pretónico de sete unidades, que algúns autores consideran que está xa asentado na fala (Álvarez et al. 1995; Fernández Rei \& Regueira 2017: 99; Regueira 2016).

Outro dos factores considerados na análise, o sexo, non parece estar relacionado coa escolla dun ou doutro modelo de vocalismo pretónico. Con respecto á procedencia e á variedade dialectal dos falantes, os resultados mostran que o vocalismo pretónico formado por sete unidades só está presente en falantes de procedencia rural e só un deles pertence ao bloque occidental. Con todo, este modelo é minoritario pois todos os falantes presentan un certo grao de solapamento entre as vogais medias altas e medias baixas, fundamentalmente na serie anterior $([\mathrm{e}]-[\varepsilon])$, polo que cómpre tomar con cautela estes resultados. 

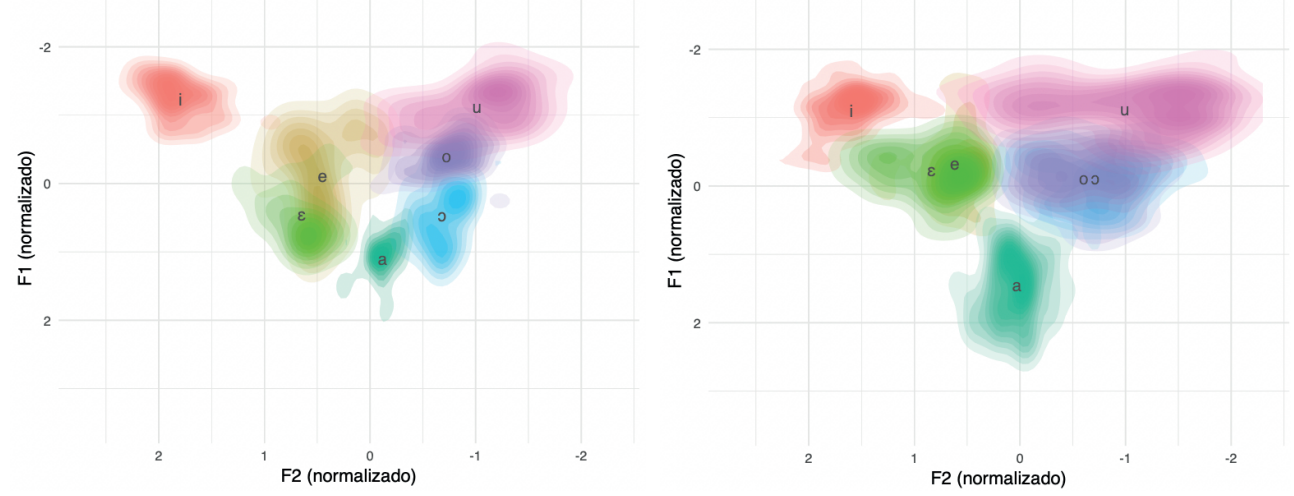

Figura 9. Gráficos de densidade do F1 e do F2 das vogais átonas iniciais segundo cada modelo presente na mostra analizada

Os datos deste estudo mostran tamén dúas características salientables no vocalismo pretónico, que son a centralización da vogal media alta anterior [e] en ambos os dous modelos e a elevación da vogal central /a/ (producida como [e]), que é lixeiramente máis baixa no modelo de cinco unidades ca no modelo de sete unidades. Ambos os dous fenómenos son característicos do portugués europeo e responden a procesos fonolóxicos específicos desta lingua (Bisol \& Veloso 2016; Veloso 2016), pero non temos constancia da existencia de ningún traballo que documente ou que faga referencia a estas características do vocalismo pretónico no galego. Se ben hai autores como Taboada (1979) ou Regueira (2010) que aluden á diferente realización das vogais átonas con respecto ás tónicas, non indican en que dirección se produce esta variación.

\subsubsection{Vocalismo átono final}

No mesmo sentido ca en Molinos Castro (2002) e Regueira (2007), os resultados deste estudo mostran un vocalismo átono final que se caracteriza por unha acusada centralización e elevación con respecto ao vocalismo tónico. Pero, ademais, as vogais medias do vocalismo átono final mostran unha forte variación, tal e como se observa no gráfico da Figura 10. 


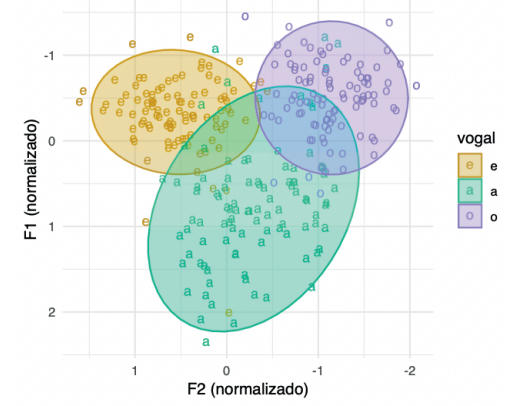

Figura 10. Gráfico de dispersión das vogais postónicas finais (F1 e F2 normalizados) para o conxunto de datos da mostra. As elipses marcan a dispersión con respecto á media cun intervalo de confianza do $95 \%$

Apréciase tamén un lixeiro solapamento entre a vogal central baixa e as vogais medias anterior e posterior. Este solapamento é debido fundamentalmente á centralización das vogais medias nesta posición acentual e á elevación da vogal central, aínda máis acusada ca en posición átona inicial de palabra. Aínda que este solapamento é lixeiramente maior nas mulleres ca nos homes, o cálculo do coeficiente Bhattacharyya (vid. Táboa 4) non nos permitiu delimitar modelos diferenciados de vocalismo átono final, senón que apuntou a unha forte homoxeneidade entre falantes, que contrasta coa heteroxeneidade existente no vocalismo tónico e átono inicial que viamos nos apartados anteriores.

\begin{tabular}{|c|c|c|c|c|c|}
\hline Falante & Hábitat & Bloque & [I]-[G] & [I]-[ซ] & [в]-[ซ] \\
\hline $\mathrm{HO1}$ & Rural & Central & 0.08 & 0.22 & 0.16 \\
\hline H02 & Urbano & Occidental & 0.13 & 0.0 & 0.03 \\
\hline H06 & Urbano & Occidental & 0.09 & 0.07 & 0.16 \\
\hline HO9 & Rural & Occidental & 0.27 & 0.24 & 0.11 \\
\hline $\mathrm{H} 10$ & Urbano & Occidental & 0.04 & 0.01 & 0.02 \\
\hline $\mathrm{H} 11$ & Rural & Central & 0.09 & 0.14 & 0.27 \\
\hline M04 & Rural & Central & 0.13 & 0.06 & 0.29 \\
\hline M05 & Rural & Occidental & 0.28 & 0.23 & 0.4 \\
\hline M06 & Rural & Central & 0.44 & 0.14 & 0.59 \\
\hline M07 & Rural & Occidental & 0.33 & 0.06 & 0.49 \\
\hline M12 & Rural & Occidental & 0.63 & 0.18 & 0.65 \\
\hline M21 & Rural & Central & 0.33 & 0.03 & 0.26 \\
\hline
\end{tabular}

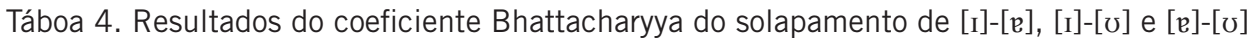
átonas finais para cada un dos falantes 
Esta homoxeneidade entre falantes no vocalismo átono final, que se plasma na Figura 11, resulta especialmente interesante se temos en conta que a redución e centralización que presenta forman parte dun proceso fonolóxico específico do galego, semellante ao do portugués europeo pero inexistente en castelán estándar (Hualde 2014: 121).

Xa que logo, de acordo cos nosos datos o contacto co español non parece afectar á realización do vocalismo átono final dos falantes da nosa mostra, xa que en todos os casos se manifesta un proceso de elevación e de centralización, pese a que unha parte importante deles presenta modelos de vocalismo pretónico e tónico coincidentes cos do español.

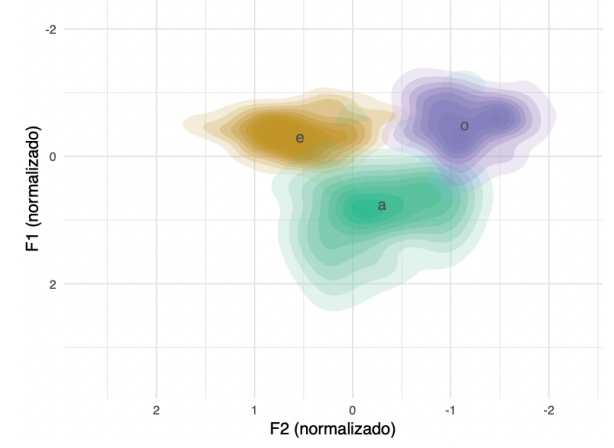

Figura 11. Gráfico de densidade do F1 e do F2 das vogais átonas finais para o único modelo existente segundo a mostra analizada

\section{CONCLUSIÓNS}

Neste traballo presentamos os resultados exploratorios dun estudo de descrición acústica do vocalismo galego falado pola mocidade universitaria en contextos formais, abordando o efecto do contacto co castelán sobre a variación observada e tendo en conta tamén varios factores vinculados coa variación lingüística.

Os resultados mostraron a existencia de dous modelos de vocalismo tónico na nosa mostra. Un destes modelos é semellante ao vocalismo tónico descrito para o galego tradicional por autores como Veiga (1976) e Álvarez e Xove (2002) 
e as características acústicas deste modelo coinciden globalmente coas que presentan González González \& Regueira (1994). O outro modelo de vocalismo tónico existente na nosa mostra coincide co vocalismo tónico do castelán (Hualde 2014), xa que se caracteriza pola fusión de [e]-[ع] e de [o]-[o], dando como resultado en ambos os dous casos unha vogal media intermedia entre as dúas categorías de cada serie.

Os resultados obtidos neste estudo dan conta tamén da relevancia do hábitat de residencia dos falantes no mantemento da oposición entre as vogais medias altas e medias baixas, xa que unicamente falantes de procedencia rural producen os contrastes entre $[\mathrm{e}]-[\varepsilon]$ e entre [o]-[o] tónicas e átonas iniciais. Estes achados concordan cos resultados obtidos noutros estudos sobre a produción e a percepción do vocalismo (Aguete Cajiao 2017; Tomé Lourido 2018; tomé Lourido \& Evans 2015, 2019), pero tamén en traballos sobre entoación (Pérez Castillejo 2012) ou léxico (Álvarez de la Granja \& López Meirama 2013), nos que se observa que a procedencia rural dos falantes está relacionada cun uso dos padróns de entoación propios do galego e cunha preferencia pola escolla de formas galegas cando falan castelán.

Pese a que os resultados deste estudo deben ser tomados con cautela, debido ao tamaño da mostra e ao grupo de falantes no que se basea este traballo, si mostran unha tendencia á converxencia do vocalismo galego do castelán. Con todo, a existencia doutros traballos con resultados semellantes, como o de Mayr et al. (2019), apoia a validez dos nosos resultados. Os resultados de ambos os dous traballos corroboran que este sistema "innovador" está presente, polo menos, en contextos e usos formais de galego.

Con respecto ao vocalismo átono inicial, os nosos resultados tamén fan evidente a existencia de dous modelos, un deles coincidente co sistema pretónico descrito por Santamarina (1974) como "moderno", que presenta a oposición entre [e]-[ع] e entre [o]-[0], e outro modelo, caracterizado pola fusión deses dous contrastes e que, a priori, coincide formalmente co vocalismo pretónico "arcaico" de Santamarina. Pese a que na lingüística galega se asume que ese vocalismo átono inicial de sete unidades descrito inicialmente por Santamarina está totalmente asentado na fala, a súa presenza na nosa mostra é moi minoritaria e manifesta unha notable variabilidade difícil de sistematizar. Por outra banda, cómpre salientar que ambos os dous modelos presentan dous procesos inexistentes en castelán, pero propios do proceso de redución do vocalismo átono compartido polo 
galego e o portugués: a elevación xeneralizada das vogais máis baixas, que afecta fundamentalmente á vogal central /a/, e a centralización da vogal anterior /e/.

En contraste coa variación existente no vocalismo tónico e no vocalismo átono inicial, os resultados mostran unha forte homoxeneidade entre falantes no vocalismo átono en final de palabra, caracterizado por un dobre proceso de elevación e centralización, semellante ao que se describe para o vocalismo átono inicial, pero máis acusado.

Existe a posibilidade de que os falantes analizados que presentan un sistema vocálico tónico innovador empreguen noutras situacións un vocalismo conservador. Segundo esta hipótese, que non podemos comprobar a partir dos datos que temos actualmente, estariamos ante un caso de acomodación, nunha liña semellante á suxerida por Mayr et al. (2019), o que estaría indicando que o modelo fonético de maior prestixio para estes falantes é semellante ao do castelán. O feito de que exista unha relación entre o hábitat urbano, onde hai unha maior presenza do castelán, e o modelo innovador, apoia esta interpretación.

Comprobamos ademais que existe unha serie de factores internos que poden estar favorecendo a perda do contraste entre /e/-/E/ e entre/o/-/o/; concretamente, a baixa rendibilidade asociada ao contraste en comparación cos restantes contrastes vocálicos. Ademais, os resultados acústicos obtidos neste estudo experimental mostraron que mesmo os falantes conservadores presentan un certo grao de solapamento entre [e]-[ع] e entre [o]-[0], que pode estar reflectindo un proceso de fusión por aproximación (Labov 1996), é dicir, un proceso gradual e sistémico, do que os falantes non son conscientes. A inestabilidade da oposición entre as vogais medias altas e as vogais medias baixas e a fusión destes dous pares de vogais está documentado noutras linguas románicas coma o catalán (Recasens \& Espinosa 2009, Bosch-Roura 2017), o italiano (Renwick \& Ladd 2016, Maiden 1997), o francés (Landick, 1995) e o romanés (Renwick, 2015). No portugués europeo, Escudero et al. (2009) tamén atopan evidencias dun posible cambio en marcha no que se fusionan as vogais anteriores media alta e media baixa /e/-/ع/.

Os resultados tamén permiten dar conta da redución do vocalismo átono, especialmente no vocalismo átono final, mantense de xeito homoxéneo en todos os falantes da mostra, a pesar de ser esta unha característica específica do galego e prominente con respecto ao castelán. Resulta paradoxal considerar que o contacto co castelán afecta ao sistema vocálico eliminando un contraste fonolóxico 
e non afectando a un proceso de redución con consecuencias fonéticas. Poderiamos hipotetizar que este proceso de redución tamén se dá no castelán de Galicia pero os poucos traballos que indirectamente presentan datos ao respecto sinalan que a redución existente no castelán de Galicia é moi inferior á do galego (Regueira \& Fernández Rei 2020; Tomé Lourido \& Evans 2019). Por outra banda, tamén cabe considerar a posibilidade de que os falantes innovadores empreguen un vocalismo átono tradicional de forma consciente, como un marcador de identidade, tal e como suxire Tomé Lourido (2018). Este tipo de comportamento atópase noutras linguas, especialmente cando se produce a perda dunha característica asociada a unha identidade. Dyer (2007: 102), por exemplo, menciona o caso da comunidade Cajun en Louisiana, na que os falantes máis novos substituíron o uso do francés, que fora a lingua comunitaria pero que xa non falan, polo uso do inglés con acento francés para marcar a súa identidade.

En definitiva, os resultados das investigacións evidencian un posible proceso de nivelación que afecta ao vocalismo tónico do galego e que ten como consecuencia a eliminación das características que o diferencian do castelán, é dicir, o contraste entre as vogais medias altas e medias baixas. Con todo, o efecto do contacto non pode explicar por si só a variación observada, senón que resulta indispensable acudir a motivacións extralingüísticas asociadas ás actitudes e identidades dos falantes, o que pon de relevo a necesidade de ampliar esta liña de traballo.

\section{AGRADECEMENTOS}

Quero mostrar o meu fondo agradecemento a Xulio Sousa, Francisco Dubert e Vítor Míguez por convidarme a participar nesta publicación e especialmente pola súa paciencia e apoio. A eles agradézolles ademais os comentarios e correccións. Agradezo tamén a Elisa Fernández Rei as interesantes observacións feitas a unha versión previa deste capítulo que contribuíron a melloralo significativamente. 


\section{REFERENCIAS BIBLIOGRÁFICAS}

Aguete Cajiao, Alba. 2017. Factores externos na variación do vocalismo galego. Estudo perceptivo. En X. L. Regueira \& E. Fernández Rei (eds.), Estudos sobre o cambio lingüistico no galego actual, 63-97. Santiago de Compostela: Consello da Cultura Galega.

Aguete Cajiao, Alba. 2019. Vocalismo galego. Motivacións fonolóxicas do cambio. [Tese de doutoramento]. Universidade de Santiago de Compostela.

Álvarez Blanco, Rosario. 1991. O sistema fonolóxico do galego. Comparación co do portugués. En Actes du XVIII Congrès International de Linguistique et de Philologie Romanes (Université de Trier, 1986), vol. 3 , 517-530. Tübingen: Max Niemeyer.

Álvarez de la Granja, María \& Belén López Meirama. 2013. A presenza do galego no léxico dispoñible do español de Galicia. Análise distribucional. En E. Gugenberger, H. Monteagudo \& G. Rei-Doval (eds.), Contacto de linguas, hibrididade, cambio: contextos, procesos e consecuencias, 49-96. Santiago de Compostela: Consello da Cultura Galega / Instituto da Lingua Galega.

Álvarez, Rosario, Henrique Monteagudo \& Xosé Luís Regueira. 1995 [1986]. Gramática galega. Vigo: Galaxia.

Álvarez, Rosario \& Xosé Xove. 2002. Gramática da lingua galega. Vigo: Galaxia.

Amengual, Mark \& Pilar Chamorro. 2015. The effects of language dominance in the perception and production of the Galician mid vowel contrasts. Phonetica 72. 207-36. https://doi.org/10.1159/000439406

Auer, Peter. 2007. Mobility, Contact and Accommodation. En C. Llamas, L. Mullany \& P. Stockwell (eds.), The Routledge Companion to Sociolinguistics, 109-115. New York: Routledge.

Baayen, R. H. 2008. Analyzing linguistic data. A practical introduction to statistics using $R$. Cambridge: Cambridge University Press.

Berruto, Gaetano. 1995. Fondamenti di sociolinguistica. Roma / Bari: Laterza.

Berruto, Gaetano. 2005. Dialect/Standard convergence, mixing and models of language contact: the case of Italy. En P. Auer, F. Hinskens \& P. Kerswill (eds.), Dialect change. Convergence and Divergence in European Languages, 81-95. New York: Cambridge University Press.

Best, Catherine T., Gerald W. McRoberts \& Elizabeth Goodell. 2001. Discrimination of non-native consonant contrasts varying in perceptual assimilation to the listener's native phonological system. Journal of the Acoustical Society of America 109(2). 775-794. https://doi.org/10.1121/1.1332378

Bhattacharyya, Anil. 1943. On a Measure of Divergence between Two Statistical Populations Defined by Their Probability Distributions. Bulletin of the Calcutta Mathematical Society 35. 99-109.

Bisol, Leda \& João Veloso. 2016. Phonological Processes Affecting Vowels. En W. Leo Wetzels, S. Menuzzi \& João Costa (eds.), The Handbook of Portuguese Linguistics, 69-85. Malden, MA: Wiley-Blackwell.

Boersma, Paul \& David Weenink. 2010. PRAAT: Doing phonetics by computer. https://www.fon.hum.uva. nl/praat/

Bosch-Roura, Eva. 2017. Les vocals mitjanes posteriors en el català de Girona. Anàlisi de la producció i la percepció. [Tese de doutoramento]. Universitat de Barcelona.

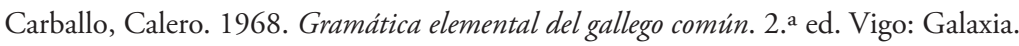

Clopper, Cynthia G., David B. Pisoni \& Kenneth de Jong. 2005. Acoustic Characteristics of the Vowel Systems of Six Regional Varieties of American English. Journal of the Acoustical Society of America 3(118). 1661-1676. https://doi.org/10.1121/1.2000774 
Couceiro, Xosé Luís. 1976. El habla de Feás. Verba. Anexo 5.

Croft, William. 2000. Explaining Language Change. An evolutionary approach. Londres: Longman.

De la Fuente Iglesias, Mónica \& Susana Pérez Castillejo. 2019. Phonetic interactions in the bilingual production of Galician and Spanish /e/ and /o/. International Journal of Bilingualism. 1-14. https://doi. org/10.1177/1367006919826868

Dubert García, Francisco. 2002. Os sociolectos galegos. Cadernos de Lingua 24. 5-27.

Dubert García, Francisco. 2005. Interferencias del castellano en el gallego popular. Bulletin of Hispanic Studies (Liverpool. 2002) 82(3). 271-293. https://doi.org/10.3828/bhs.82.3.1

Dyer, Judy. 2007. Language and Identity. En C. Llamas, L. Mullany \& P. Stockwell (eds.), The Routledge Companion to Sociolinguistics, 101-8. New York: Routledge.

Escudero, Paola, Paul Boersma, Andréia Schurt Rauber \& Ricardo A. H. Bion. 2009. A cross-dialect acoustic description of vowels: Brazilian and European Portuguese. Journal of the Acoustical Society of America 126(3).1379-1393. https://doi.org/10.1121/1.3180321

Fernández Rei, Elisa \& Xosé Luís Regueira. 2017. Situando o galego no terreo da investigación lingüística: os traballos de fonética e fonoloxía. LaborHistórico 3(1). 93-110. https://doi.org/10.24206/lh.v3i1.17109

Fernández Rei, Francisco. 1990. Dialectoloxía da lingua galega. Vigo: Xerais.

Fernández Salgado, Xosé Antonio. 2004. A interferencia do castelán no léxico galego: o castelanismo como recurso eufemístico. En R. Álvarez Blanco, F. Fernández Rei \& A. Santamarina (eds.), A lingua galega: historia e actualidade, vol. 1, 501-507. Santiago de Compostela: Consello da Cultura Galega / Instituto da Lingua Galega.

Field, A., J. Miles \& Z. Field. 2012. Discovering statistics using R. London: Sage.

Flege, James Emil. 1987. The production of "new" and "similar" phones in a foreign language: evidence for the effect of equivalence classification. Journal of Phonetics $15.47-65$. https://doi.org/10.1016/s00954470(19)30537-6

Flege, James Emil. 1993. Production and perception of a novel, second-language phonetic contrast. The Journal of the Acoustical Society of America 93(3).1589-1608. https://doi.org/10.1121/1.406818

Flynn, Nicolas. 2011. Comparing vowel formant normalisation procedures. York Working Papers in Linguistics 11. 1-28.

Freixeiro Mato, Xosé Ramón. 2001. Manual de gramática galega. Vigo: A Nosa Terra.

Freixeiro Mato, Xosé Ramón. 2006. Gramática da lingua galega, vol. I. Vigo: A Nosa Terra.

Freixeiro Mato, Xosé Ramón. 2014. Lingua oral, calidade da lingua e futuro do galego. En X. M. Sánchez Rei (ed.), Modelos de lingua e compromiso. A Coruña: Baía Edicións.

González González, Manuel. 2008. O novo galego urbano. En M. Brea, F. Fernández Rei \& X. L. Regueira (eds.), Cada palabra pesaba, cada palabra medía. Homenaxe a Antón Santamarina. Santiago de Compostela: Servizo de Publicacións e Intercambio Científico da USC.

González González, Manuel \& Xosé Luís Regueira Fernández. 1994. Estudio acústico das vocais tónicas galegas en posición fonética normal. En R. Lorenzo (ed.), Actas do XIX Congreso Internacional de Lingüistica e Filoloxía Románicas, vol. VI, 141-179. A Coruña: Fundación Pedro Barrié de la Maza, Conde de Fenosa. 
Gugenberger, Eva. 2013. O cambio de paradigma nos estudos sobre contacto lingüístico: pode ser útil o concepto de hibrididade para a lingüística e a política de linguas en Espańa? En E. Gugenberger, H. Monteagudo \& G. Rei-Doval (eds.), Contacto de linguas, hibrididade, cambio: contextos, procesos e consecuencias, 17-47. Santiago de Compostela: Consello da Cultura Galega / Instituto da Lingua Galega.

Gugenberger, Eva, Henrique Monteagudo \& Gabriel Rei-Doval (eds.) 2013. Contacto de linguas, hibrididade, cambio: contextos, procesos e consecuencias. Santiago de Compostela: Consello da Cultura Galega / Instituto da Lingua Galega.

Hall, Kathleen Currie. 2013. A typology of intermediate phonological relationships. The Linguistic Review 30(2). 215-275. https://doi.org/10.1515/tlr-2013-0008

Hayward, Katrina. 2000. Experimental phonetics. Harlow: Longman.

Hickey, Raymond. 2012. Internally- and Externally- Motivated Language Change. En J. M. Hernández Campoy \& J. C. Conde-Silvestre (eds.), The Handbook of Historical Sociolinguistics. 387-407. Malden: Wiley-Blackwell

Hinskens, F., P. Auer \& P. Kerswill. 2005. The study of dialect convergence and divergence: conceptual and methodological considerations. En Auer, P., F. Hinskens \& P. Kerswill (eds.), Dialect change. Convergence and Divergence in European Languages. 1-48. New York: Cambridge University Press.

Hockett, Charles F. 1967. The quantification of functional load. Word 23. 320-339. https://doi.org/10.10 80/00437956.1967.11435484

Hualde, José Ignacio. 2014. Los sonidos del español. Cambridge: Cambridge University Press.

Hualde, José Ignacio \& Fernando Martínez-Gil. 1994. Un análisis autosegmental de ciertas alternancias vocálicas en el gallego moderno. En R. Lorenzo (ed.), Actas do XIX Congreso Internacional de Lingüistica e Filoloxía Románicas, vol. VI, 181-195. A Coruña: Fundación Pedro Barrié de la Maza, Conde de Fenosa.

Hume, Elizabeth \& Keith Johnson. 2001. A model of the interplay of speech perception and phonology. En E. Hume \& K. Johnson (eds.), The role of Speech Perception in Phonology, 3-26. San Diego: Academic Press.

IGE. 2011. Clasificación do grado de urbanización das parroquias e concellos galegos (GU2011). Xunta de Galicia.

Iglesias Álvarez, Ana. 2016. Castelanismos e galeguismos. A súa relación co estándar. Estudos de Lingüistica Galega 8. 107-125. https://doi.org/10.15304/elg.8.3074

Johnson, Daniel Ezra. 2015. Quantifying Overlap with Bhattacharyya’s affinity and other measures. Presentado en New Ways of Analyzing Variation 44, Toronto.

Jones, Mari C. \& Edith Esch (eds.). 2002. Language Change. The Interplay of Internal, External and ExtraLinguistic Factors. Berlin: Mouton de Gruyter.

Kerswill, Paul. 2013. Identity, ethnicity and place: the construction of youth language in London. En P. Auer, M. Hilpert, A. Stukenbrock \& B. Szmrecsanyi (eds.), Space in language and linguistics. Linguae and literae, 128-164. Walter de Guyter.

Kerswill, Paul \& A. Williams. 2002. "Salience" as an explanatory factor in language change: evidence from dialect levelling in urban England. En M. Jones \& E. Esch (eds.), Language Change: The Interplay of Internal, External and Extra-Linguistic Factors, 81-110. Berlin / New York: Mouton de Gruyter.

Kuhl, P. K. \& P. Iverson. 1995. Linguistic experience and the "Perceptual Magnet Effect". En W. Strange (ed.), Speech perception and linguistic experience: Issues in cross linguistic research, 121-54. Baltimore, MD: York Press. 
Kuhl, P. K., K. A. Williams, F. Lacerda, K. N. Stevens \& B. Lindblom. 1992. Linguistic Experience Alters Phonetic Perception in Infants by 6 Months of Age. Science 255(5044).606-608. https://doi. org/10.1126/science.1736364

Labov, William. 1996. Principios del cambio lingüístico, vol. 1. Madrid: Gredos.

Labov, William. 2006. Principios del cambio lingüistico, vol. 2. Madrid: Gredos.

Landick, Marie. 1995. The Mid-Vowels in Figures: Hard Facts. The French Review 69(1). 88-102.

Lausberg, Heinrich. 1971. Linguistica Romanza, vol. I: Fonética. Milano: Feltrinelli.

Levshina, N. 2015. How to do Linguistics with R. Data exploration and statistical analysis. Amsterdam / Philadelphia: John Benjamins.

Lobanov, Boris. 1971. Classification of Russian Vowels Spoken by Different Speakers. The Journal of the Acoustical Society of America 49. 606-608. https://doi.org/10.1121/1.1912396

López-Bueno, Laura. 2017. Galician-Spanish mid vowel production in Southern Galicia: using language mode to explore bilingual speakers' underlying phonological categories. [Traballo de fin de grao (BS thesis)]. Cardiff Metropolitan University.

Loredo Gutiérrez, Xaquín \& Bieito Silva Valdivia. 2014. Variables asociadas á competencia gramatical e léxica en galego e castelán do alumnado de Galicia ao final do ensino obrigatorio. Revista de Investigación en Educación 12(2). 191-208.

Lugrís Freire, Manuel. 2006. Gramática do idioma galego. Ed. facsímile. Santiago de Compostela: Consello da Cultura Galega.

Maiden, M. 1997. Vowel systems. En Maiden, M. \& M. Parry (eds.), The Dialects of Italy, 7-14. London: Routledge.

Mariño Paz, Ramón. 1998. Historia da lingua galega. Santiago de Compostela: Sotelo Branco.

Martínez Celdrán, Eugenio. 1998. Análisis espectrográfico de los sonidos del habla. Barcelona: Ariel.

Martínez-Gil, Fernando. 2019. Galician mid-vowel reduction: A Stratal Optimality Theory account. En M. Gibson \& J. Gil (eds.), Romance Phonetics and Phonology, 299-350. New York: Oxford University Press.

Mateus, María Helena Mira. 1986. Fonologia do galego e do português. En Actas do I Congresso Internacional da Lingua Galego-Portuguesa na Galiza. A Coruña: AGAL.

Mayr, Robert, Laura López-Bueno, Martín Vázquez Fernández \& Gisela Tomé Lourido. 2019. The Role of Early Experience and Continued Language Use in Bilingual Speech Production: A Study of Galician and Spanish Mid Vowels by Galician-Spanish Bilinguals. Journal of Phonetics 72. 1-16. https://doi. org/10.1016/j.wocn.2018.10.007

Milroy, Lesley. 2003. Social and linguistic dimensions of phonological change: Fitting the pieces of the puzzle together. En D. Britain \& J. Cheshire (eds.), Social Dialectology. In honour of Peter Trudgill. 155-171. Amsterdam / Philadelphia: John Benjamins.

Molinos Castro, Rita. 2002. As vocais átonas finais en galego: estudio acústico. Cadernos de Lingua 24. 55-91.

Monteagudo, Henrique. 2005. Do uso á norma, da norma ó uso (variación sociolingüística e estandarización no idioma galego). En R. Álvarez \& H. Monteagudo (eds.), Norma lingüistica e variación, 378-436. Santiago de Compostela: Consello da Cultura Galega / Instituto da Lingua Galega.

Monteagudo, Henrique, Xaquín Loredo Gutiérrez \& Martín Vázquez. 2016. Lingua e sociedade en Galicia. A evolución sociolingüistica 1992-2013. A Coruña: Real Academia Galega. 
Monteagudo, Henrique \& Antón Santamarina. 1993. Galician and Castilian in contact: historical, social, and linguistic aspects. En R. Posner \& J. N. Green (eds.), Trends in Romance Linguistics and Philology, vol. 5: Bilingualism and Linguistic Conflict in Romance. 117-173. Berlin / New York: Mouton de Gruyter. Moreno, Francisco. 2009. Principios de sociolingüistica y sociología del lenguaje. Barcelona: Ariel.

Muysken, Pieter \& Norval Smith. 1994. The study of pidgin and creole languages. En Pieter Muysken \& John Victor Singer (eds.), Pidgins and Creoles: an introduction. 3-14. Amsterdam / Philadelphia: John Benjamins.

Negro Romero, Marta. 2009. O léxico tradicional no campo semántico das partes da cabeza: proposta de recuperación nos dicionarios normativos. Estudos de Lingüistica Galega 1. 235-246. 10.3309/1989-578X09-14

Negro Romero, Marta. 2013. Contacto galego-castelán e cambio no léxico do corpo humano. En E. Gugenberger, H. Monteagudo \& G. Rei-Doval (eds.), Contacto de linguas, hibrididade, cambio: contextos, procesos e consecuencias. 221-239. Santiago de Compostela: Consello da Cultura Galega / Instituto da Lingua Galega.

Ohala, John. 1995. Experimental Phonology. En J. A. Goldsmith (ed.), The Handbook of Phonological Theory, 713-722. Oxford: Blackwell.

Pérez Castillejo, Susana. 2012. Estudio sociofonético de los tonemas de las interrogativas absolutas en el castellano de Galicia. ELUA. Estudios de Lingüistica 26. 235-68. https://doi.org/10.14198/elua2012.26.08

Pierrehumbert, Janet. 1990. Phonological and Phonetic Representation. Journal of Phonetics 18. 375-394.

Porto Dapena, José Álvaro. 1977. El gallego hablado en la comarca ferrolana. Verba. Anuario Galego de Filoloxía Anexo 9.

Quilis, Antonio. 1997. Principios de fonología. Madrid: Arco Libros.

R Core Team. 2018. R: A Language and Environment for Statistical Computing. Vienna, Austria: R Foundation for Statistical Computing.

Ramallo, Fernando. 2010. Cara a unha tipoloxía sociolingüística dos falantes de galego. En B. Silva, X. Rodríguez \& I. Vaquero (eds.), Educación e linguas en Galicia, 15-37. Santiago de Compostela: Servizo de Publicacións e Intercambio Científico da USC.

Ramallo, Fernando. 2013. Neofalantismo. En E. Gugenberger, H. Monteagudo \& G. Rei-Doval (eds.), Contacto de linguas, hibrididade, cambio: contextos, procesos e consecuencias, 245-58. Santiago de Compostela: Consello da Cultura Galega / Instituto da Lingua Galega.

Ramallo, Fernando \& Bernadette O'Rourke. 2014. Perfiles de neohablantes de gallego. Digithum 16. 98-105.

Recasens, D. \& A. Espinosa. 2009. Dispersion and variability in Catalan five and six peripheral vowel systems. Speech Communication 51. 240-258. doi:10.1016/j.specom.2008.09.002

Regueira, Xosé Luís. 2007. Vocais finais en galego e portugués: un estudo acústico. En Helena González Fernández \& M. ${ }^{a}$ Jesús Lama López (coords.), Actas VII Congreso Internacional de Estudos Galegos. Mulleres en Galicia: Galicia e os outros pobas da peninsula: Barcelona, 28 ó 31 de maio de 2003, vol. 2, 859-876. Sada, A Coruña: Ediciós do Castro.

Regueira, Xosé Luís. 2008. Cambios fonolóxicos no galego actual. En En M. Brea, F. Fernández Rei \& X. L. Regueira (eds.), Cada palabra pesaba, cada palabra medía. Homenaxe a Antón Santamarina, 275-286. Santiago de Compostela: Servizo de Publicacións e Intercambio Científico da USC. 
Regueira, Xosé Luís. 2009. Cambios fonéticos e fonolóxicos no galego contemporáneo. Estudos de Lingüistica Galega 1. 147-167. doi: 10.3309/1989-578X-09-8

Regueira, Xosé Luís. 2010. Dicionario de pronuncia da lingua galega. A Coruña: Real Academia Galega. Regueira, Xosé Luís. 2012. Autenticidade e calidade da lingua: purismo e planificación lingüística no galego actual. Estudos de Lingüistica Galega 4. 187-201.

Regueira, Xosé Luís. 2013. Estándar oral e modelos de lingua. A letra miúda 2. 1-23.

Regueira, Xosé Luís. 2016. Variación lingüística, dialectoloxía e gramática histórica: algúns problemas do cambio lingüístico en galego e portugués. En A. Rodríguez Guerra (ed.), Lingüistica histórica e dialectoloxia: coordenadas do cambio lingüistico. Vigo: Universidade de Vigo, Servizo de Publicacións.

Regueira, Xosé Luís \& Elisa Fernández Rei. 2020. The Spanish sound system and intonation in contact with Galician. En R. G. Rao (ed.), Spanish phonetics and phonology in contact: Studies from Africa, the Americas, and Spain. Amsterdam / New York: John Benjamins.

Renwick, M. E. L. 2015. Dimensions of Phonemic Contrast in Romance Vowels. Comunicación oral en Ling Lunch, Paris Diderot University (Paris 7). http://www.linguist.univ-paris-diderot.fr/_media/linglunch/ slideslinglunch-renwick-201506.pdf [Consultado: 2/05/2020].

Renwick, M. E. L. \& D. R. Ladd. 2016. Phonetic distinctiveness vs. Lexical Contrastiveness in NonRobust Phonemic Contrasts. Journal of the Association for Laboratory Phonology 7(1). 19. https://doi. org/10.5334/labphon.17 https://doi.org/10.5334/labphon.17

Rojo, Guillermo. 2005. El español de Galicia. En R. Cano (ed.), Historia de la lengua española, 1087-1101. Barcelona: Ariel.

Rosner, B. S. \& J. B. Pickering. 1994. Vowel perception and production. Oxford: Oxford University Press.

Santamarina, Antón. 1974. El verbo gallego: Estudio basado en el habla del valle del Suarna. Verba Anexo 4. Siegel, Jeff. 2008. The Emergence of Pidgin and Creole Languages. New York: Oxford University Press.

Silva Valdivia, Bieito. 2004. Converxencia e diverxencia en certas estruturas morfosintácticas do galego. En R. Álvarez \& H. Monteagudo (eds.), Norma lingüistica e variación. Unha perspectiva desde o idioma galego, 259-281. Santiago de Compostela: Consello da Cultura Galega / Instituto da Lingua Galega.

Silva Valdivia, Bieito. 2006. Castelanismos morfosintácticos no galego. Avaliación da competencia do alumnado. Santiago de Compostela: Servizo de Publicacións e Intercambio Científico da Universidade de Santiago de Compostela.

Silva Valdivia, Bieito. 2013. Galego e castelán: entre o contacto e a converxencia. En E. Gugenberger, H. Monteagudo \& G. Rei-Doval (eds.), Contacto de linguas, hibrididade, cambio: contextos, procesos e consecuencias, 289-316. Santiago de Compostela: Consello da Cultura Galega / Instituto da Lingua Galega.

Stevens, M. \& J. Harrington. 2014. The individual and the actuation of sound change. Loquens 1(1). https://doi.org/10.3989/loquens.2014.003

Taboada, Manuel. 1979. El habla del valle de Verín. Verba. Anexo 15.

Thomason, Sarah. 2001. Language Contact. Edinburgh: Edinburgh University Press.

Thomason, Sarah. 2010. Contact Explanations in Linguistics. En Hickey, Raymond (ed.), The Handbook of Language Contact, 31-47. Chichester: Wiley-Blackwell.

Tomé Lourido, Gisela. 2018. The role of social factors in bilingual speech processing: the case of Galician New Speakers. [Tese de doutoramento]. London: University College London. 
Tomé Lourido, Gisela \& Bronwen G. Evans. 2015. Switching language dominance for ideological reasons: a study of Galician new speakers' speech production and perception. En Proceedings of the 18th International Congress of Phonetic Sciences (ICPhS). Glasgow: University of Glasgow.

Tomé Lourido, Gisela \& Bronwen G. Evans. 2019. The effects of language dominance switch in bilinguals: Galician new speakers' speech production and perception. Bilingualism: Language and Cognition 22(3). 637-654. https://doi.org/10.1017/s1366728918000603

Torgersen, Eivind \& Paul Kerswill. 2004. Internal and external motivation in phonetic change: Diallect levelling outcomes for an English vowel shift. Journal of Sociolinguistics 1(8). 23-53. https://doi. org/10.1111/j.1467-9841.2004.00250.x

Trudgill, Peter. 1986. Dialects in Contact. Oxford: Basil Blackwell.

Veiga, Amable. 1976. Fonología gallega. Valencia: Bello.

Veloso, João. 2016. O sistema vocálico e a redução e neutralização das vogais átonas. En A. M. Martins \& E. Carrilho (eds.), Manual de linguistica portuguesa, Manuals of Romance Linguistics, 636-662. Berlin / Boston: De Gruyter.

Vidal Figueiroa, Tiago. 1997. Estruturas fonéticas de tres dialectos de Vigo. Verba 24. 313-332.

Warren, Paul. 2018. Quality and quantity in New Zealand English vowel contrasts. Journal of the International Phonetic Association 48(3). 305-330. https://doi.org/10.1017/s0025100317000329 
